\title{
Authority, Autonomy, and Choice: The Role of Consent in the Moral and Political Visions of Franz Kafka and Richard Posner
}

Robin West

Georgetown University Law Center, west@law.georgetown.edu

Georgetown Public Law and Legal Theory Research Paper No. 11-04

This paper can be downloaded free of charge from:

https://scholarship.law.georgetown.edu/facpub/489

http://ssrn.com/abstract $=1737920$

99 Harv. L. Rev. 384 (1985-1986)

This open-access article is brought to you by the Georgetown Law Library. Posted with permission of the author. Follow this and additional works at: https://scholarship.law.georgetown.edu/facpub

Part of the Law and Economics Commons, Law and Society Commons, Legal History Commons, and the Public Law and Legal Theory Commons 


\title{
AUTHORITY, AUTONOMY, AND CHOICE: THE ROLE OF CONSENT IN THE MORAL AND POLITICAL VISIONS OF FRANZ KAFKA AND RICHARD POSNER
}

\author{
Robin West
}

\begin{abstract}
Law-and-economics theorist Richard Posner has argued that principles of consent support wealth maximization as a rule of judicial decisionmaking. According to Posner, wealth-maximizing consensual transactions are morally desirable because they promote both well-being and autonomy. In this Article, Professor West draws on Franz Kakfa's depictions of human motivation to dispute the empirical basis of both justificatory prongs of Posner's thesis. Kafka's characters, she argues, suggest that when individuals consent to transactions, they often do so because of a desire to submit to authority, and not to maximize well-being or autonomy. Thus, Professor West concludes, Posner's identification of consent as the moral justification of wealth maximization rests on an inadequate view of human motivation.
\end{abstract}

$\mathrm{M}$ ODERN legal and political theorists strongly disapprove of authority and just as strongly approve of autonomy. These moral attitudes underlie a vast array of current liberal political and jurisprudential doctrines. Modern arguments for the moral grounds of democracy, for the legitimacy and moral worth of the free market, for the justification of criminal punishment, for limitations upon paternalistic applications of state power, for the priority of individual rights over collective welfare, and even for the legitimacy of law itself all rest on a commitment to the virtues of individual autonomy and an antipathy toward authority. ${ }^{1}$ Criticism of these institutions and

* Assistant Professor of Law, Cleveland-Marshall College of Law; Visiting Assistant Professor, Stanford Law School. I would like to thank Tom Grey, Jim Wilson, Bill Simon, Marjorie Kornhauser, Mark McConnville, and Jonathan More for their comments and criticisms on drafts of this Article and for their reflections regarding its central claims and descriptions. Any errors that remain are my own.

1 See, e.g., B. Ackerman, Social Justice in the Liberal State (ig8o) (discussing autonomy as a justification for the liberal principle of neutrality); R. DwORKIN, TAKING RIGHTS SERIOUSLY 272 ( 1977 ) (arguing that respect for autonomy underlies the liberal conception of a right to equal concern and respect and stating that "[g]overnment must treat those whom it governs with concern, that is, as human beings who are capable of suffering and frustration, and with respect, that is, as human beings who are capable of forming and acting on intelligent conceptions of how their lives should be lived"); C. FRIED, RIGHT AND WRONG 8-9 (I978) ("[R]ight and wrong have ... overriding status because they establish our basic position as freely choosing entities. That is why nothing we choose can be more important than the ground - right and wrong - for our choosing. Right and wrong are expressions of respect for persons - respect for others and self-respect."); R. POSNER, THE ECONOMICs OF JUSTICE chs. 3-4 (1981) (contending that autonomy and respect for choice and consent justify the free market and wealth maximization as goals of legal decisionmaking); Gibbons, Justifying Lav: An Explanation of the Deep Structure of American Law, 3 LAW \& PHIL. 165 (I984) (arguing that respect for individual autonomy underlies the American system of legal entitlements). See generally W. Nelson, ON Justifying DEMOCRACY (1980) (surveying autonomy-based arguments for democracy). 
policies often reflects the same moral attitudes; critics charge that, appearances notwithstanding, the modern liberal state - indeed perhaps any state - is "hierarchical" or "authoritarian." "Choice" and "autonomy" are becoming synonyms for "right" and "good," while "submission," "obedience," "authority," and "authoritarian" conjure up the good German, the Nazi soldier, the Stalinist, and the intolerant Falwellian social leader.

In "The Ethical and Political Basis of Wealth Maximization"3 and two related articles, ${ }^{4}$ Professor (now Judge) Richard Posner argues that these widely shared pro-autonomy moral values are furthered by the wealth-maximizing market transfers, judicial decisions, and legal institutions advocated by members of the "law and economics" school of legal theory. Such transactions, decisions, and institutions are morally attractive, Posner argues, because they support autonomy; wealthmaximizing transfers are those to which all affected parties have given their consent. Posner justifies not only classic two-party market transactions on this ground, but also wealth-maximizing market transactions that allocate risk instead of commodities, and wealth-maximizing transfers effected by legal imperatives that operate independently of markets. According to Posner, even the apparent losers in wealthmaximizing transactions have consented to them in a significant moral sense. Wealth-maximizing transfers therefore rest not only on utilitarian considerations for their moral legitimacy, but also on the independent ground that they promote autonomy. Posner finds the latter, Kantian moral tradition ${ }^{5}$ more appealing than the economists' traditional utilitarian heritage. He consequently regards his discovery of the compatibility of wealth maximization and our pro-autonomy moral commitments as important evidence of the moral attractiveness of wealth maximization as a rule of judicial decisionmaking. ${ }^{6}$

This Article argues that Posner's attempt to defend wealth maximization on principles of consent rests on a simplistic and false psychological theory of human motivation. Posner's argument depends

2 See, e.g., R. WolfF, IN DEFense of ANARChism i6-I9 (1970).

${ }^{3}$ This article first appeared as Posner, The Ethical and Political Basis of the Efficiency Nom in Common Law Adjudication, 8 HoFsTRA L. REV. 487 (1980). It reappears, with some revisions, as chapter four of R. POSNER, supra note I, retitled "The Ethical and Political Basis of Wealth Maximization." References will be made to this version.

"See Posner, Utilitarianism, Economics, and Legal Theory, 8 J. Legal Stud. 103 (1979); Posner, The Value of Wealth: A Comment on Dworkin and Kronman, 9 J. LEGaL STUd. 243 (I980). The I979 article reappears as chapter three of R. POSNER, supra note I, retitled "Utilitarianism, Economics, and Social Theory." References will be made to this version.

${ }^{5}$ For Kant and modern Kantians, freedom and autonomy, not wealth, happiness, or other measures of "goodness," are the desired ends of moral decisionmaking; autonomous will is the necessary condition for a moral decision. For a bibliography of Kant's writing on morals and of modern commentaries on Kantian ethics, see Walsh, Kant, Immanuel, 4 ENCYCLOPEDIA of PhILOSOPHY 305, 317-I9, 324 (1967).

- See R. POSNER, supra note I. 
both on an explicit assumption that the presence of consent, without more, satisfies the requirements of an ideal of autonomy and on an implicit assumption that people consent to changes in their worlds in order to improve their well-being. Posner infers from these assumptions that the more "acts of consent" or "opportunities for choice" that the legal system allows, encourages, or mimics, the better off and more autonomous we will all be, and consequently the more moral our world will be. ${ }^{7}$ Posner concludes that the legal world should be governed by one overarching normative principle: the legal system ought to give people exactly what they think they want or, when that is not possible, what the legal system thinks they think they want. By doing so, Posner argues, the legal system will promote a more autonomous and wealthy world.

Through a series of contrasts, I will argue that Franz Kafka's fictional works on the nature of law ${ }^{8}$ dramatize a dark underside of Posner's argument that the fact of consent morally legitimates our legal, social, and personal worlds. Kafka's fictional characters typically consent to market transactions, employers' imperatives, and legal and familial authority, and thereby get exactly what they think they want. In Kafka's fictional and horrific world, as in Posner's theoretical and ideal one, victim, aggressor, and community all regard this consent as validating otherwise unappealing states of affairs. Consent insulates these situations from moral criticism and renders them, without more, morally attractive. In both worlds, consent is a moral trump. Kafka's fictional world thus provides a dramatic enactment of Posner's normative claim: Posner argues that consent morally legitimates all; Kafka illustrates what a world so legitimated might look and feel like. In both worlds, good and evil, and right and wrong, lose all meaning when all that matters is whether and to what extent people get exactly what they think they want.

${ }^{7}$ See id. at $65-73,92-99$.

${ }^{8}$ Kafka wrote a great deal about the nature of law and legal authority. This Article will draw upon Kafka's novel, The Trial, the stories "The Judgment," "The Refusal," and "A Hunger Artist," and the parables "The Problem of Our Laws," "The Imperial Colonel," and "The Emperor." These works do not, however, constitute an exhaustive list of Kafka's writings on the nature of law and legal authority. The parables "The New Advocate" and "Advocates," the story "In the Penal Colony," and the novel The Castle also deal with the nature of law and the motivations for obedience to political authority.

Kafka's training in law and his work in the law-related field of industrial safety for most of his adult life account for part of his deep understanding of the psychological mechanisms of consent and obedience to legal authority. Kafka's decision to go to law school was largely a submissive one: he could not build a passion for the hard sciences, and he did not feel capable of studying philosophy. Fis legal education, which he found boring and detestable, focused on the dry study of the Germanic Code. See E. Pawel, The Nightmare of Reason: A Life OF FRANZ KAFKA II7-22 (I984) (reporting that, according to Kafka, the study of law had the intellectual excitement of chewing sawdust that had been pre-chewed by thousands of other mouths"). 
Yet Kafka's world is tragic and ironic, while Posner's theoretical world is a satisfied and apparently happy one. Even if Posner's ideal world strikes the reader as a sad one, his hypothetical legal actors experience it as a wealthy and satisfactory place. By contrast, even when Kafka's world strikes the reader as funny, his characters experience it as nightmarish. I will argue that this fundamental difference between the two worlds results from Posner's and Kafka's divergent depictions of human nature. Posner's world is populated by characters who are relentlessly egoistic and as psychologically simplistic as the moral rule they live by. In Posner's stories, criminals, contractors, law-abiding citizens, legislators, and judges enter into transactions, both with others and with the state, for only one reason - to maximize their own welfare. As long as they are reasonably well informed of the choices and the nature of the risks presented to them, they are for the most part pleased with the outcomes of their decisions. Kafka's world, by contrast, is peopled by excessively authoritarian personalities. Kafka's characters usually do what they do - go to work in the morning, become lovers, commit crimes, obey laws, or whatever not because they believe that by doing so they will improve their own well-being, but because they have been told to do so and crave being told to do so. Whereas Posner's characters relentlessly pursue autonomy and personal well-being, Kafka's characters just as relentlessly desire, need, and ultimately seek out authority.

The disjunction between a system that formally and outwardly insists upon the legitimating function of consent and a human personality that inwardly and persistently seeks the security of authority accounts for much of the alienation in the lives of Kafka's characters. That disjunction between the outward descriptions imposed upon the transactions in which Kafka's characters are engaged and the radically different inward experience of those transactions by the parties involved is, I believe, deeply familiar to the modern reader. ${ }^{9}$ Kafka's characters, despite the bizarre situations in which they find themselves, are strikingly recognizable: although their outer worlds are bizarre, we have no trouble seeing ourselves and our neighbors in the inner worlds of Georg of "The Judgment" or Joseph $\mathrm{K}$. of The Trial.

9 Joyce Carol Oates makes the point in this way:

Though the words "Kafkan" and "Kafkaesque" invariably point to paradox and human frustration, and suggest childhood memories of terrifying disproportion, it is the case nonetheless that Franz Kafka's stories and parables are not at all difficult to read and to understand. . . His unique yet powerfully familiar world can be entered by any reader and comprehended feelingly at once, regardless of background or literary training. (In fact, unsophisticated - which is to say unprejudiced - readers respond to Kafka most directly, as he would have wished. Perceptive teenagers love him not because he is "one of the great moderns" but because he speaks their private language by speaking so boldly in his own.)

Oates, Kafka as Storyteller, in F. KAFKa, The Complete Stories aNd PARABLES at ix, xi (I983) [hereinafter cited as STORIES]. 
By contrast, the lack of any disjunction between Posner's simple legal and moral system and his characters' simple welfare-maximizing inner worlds renders those characters unfamiliar to the same audience. Posner's actors, despite the ordinariness of the situations in which they find themselves, are not recognizable as ourselves or our neighbors. His wealth-maximizing, racially discriminating employer, ${ }^{10}$ his wealthmaximizing criminal who decides how best to use his opportunity time and his burglar's tools, ${ }^{11}$ and his wealth-maximizing tort victim who is compensated ex ante for an accident uncompensated ex post ${ }^{12}$ do not resemble the bigoted bosses, the petty thieves, or the impoverished and paraplegic accident victims we may work with, know, or be. The inner lives and motivations of Posner's characters, although engaged in such familiar situations, are strikingly unrecognizable. They are not we, and their stark inner lives are not ours.

\section{The Role of Consent in Normative Justifications of the MARKet, RISK, AND THE STATE}

In "The Ethical and Political Basis of Wealth Maximization," Posner sets out to demonstrate that all wealth-maximizing transfers are consensual in order to provide moral grounding for his claim that judges ought to adopt wealth maximization as the primary normative goal of judicial decisionmaking. ${ }^{13}$ Posner treats wealth-maximizing transfers in three discrete classes: market transactions without thirdparty effects, market transactions with adverse third-party effects where the third-party losers have at an earlier point consented to the risk of loss, and transfers effected by operation of nonmarket legal institutions. Each of these types of transactions or transfers, Posner argues, are consensual in an important moral sense. ${ }^{14}$ States of affairs reached through such consensual transactions or transfers are thus morally attractive. ${ }^{15}$

As Posner concedes, however, each class of transfers involves a different kind of consent. First, he notes, wealth-maximizing market transactions with no third-party effects elicit the express consent of all parties affected by the exchange. ${ }^{16}$ Second, Posner argues, wealthmaximizing market transfers with adverse third-party effects elicit the implied consent of those third parties who have at some earlier time

${ }^{10}$ See R. POSNER, supra note I, at 359-63.

11 See R. Posner, Economic ANalysis of LaW 164-67 (1973).

12 See R. PoSNER, supra note I, at 95-97.

${ }^{13}$ See id. at $88-98$.

${ }^{14}$ See id. at $92-99$.

15 See id. at 90 .

16 See id. at 88-89. 
voluntarily assumed the risk of the loss. ${ }^{17}$ Third, Posner argues, wealth-maximizing institutions that operate outside the market altogether, such as the negligence system of tort law, command the hypothetical consent of all affected parties: if asked, all affected parties, including eventual losers, would consent to the imposition upon them of the nonmarket imperatives. ${ }^{18}$ Such hypothetical consent can be imputed to parties whenever the nonmarket imperative in question is wealth maximizing. Even nonmarket wealth-maximizing institutions, then, are morally justified because they are grounded on the consent - albeit on an attenuated, hypothetical consent - of even their eventual victims.

Thus, in all three types of wealth-maximizing transfers, winners and losers either expressly, impliedly, or hypothetically consent to the gains or losses they ultimately sustain. Even wealth-maximizing transactions or institutions that ultimately hurt a class of people are morally desirable both because they increase the collective wealth and because they command some sort of consent from all parties affected by the exchange. Posner concedes that a wealth-maximizing transfer does not necessarily increase the collective well-being, as opposed to the wealth, of the affected parties. Because one person's subjective happiness cannot be quantifiably compared with another's subjective pain, the quantity of overall well-being or subjective utility is simply unknowable. ${ }^{19}$ As a class, then, wealth-maximizing transactions cannot be justified on pure utilitarian grounds. Nor, Posner argues, does every wealth-maximizing transfer command the express consent of all affected parties. Wealth-maximizing transfers therefore cannot be justified as a class on the ground of pure consensual autonomy. Posner argues that, contrary to conventional wisdom, neither a showing of utility maximization nor a showing of Pareto superiority ${ }^{20}$ is necessary to the moral justification of wealth-maximizing transactions. All wealth-maximizing transfers elicit from all affected parties some form of consent - either express, implied, or hypothetical - any species of which is sufficient to legitimate the resulting state of affairs. Therefore, in Posner's view, wealth maximization rests neither on pure utilitarian grounds nor on the pure Kantian ground of achieving au-

${ }^{17}$ See id. at $94-99$.

18 See id. at 95-97. Posner sometimes speaks in terms of a single category of nonexpress consent, variously described as "implied," "implicit," and "hypothetical." In this Article, I use the phrase "implied consent" to designate the type of consent involved in transfers impasing losses on third parties who earlier consented to the risk of the ultimate loss, and "hypothetical consent" to designate the type of consent involved in nonmarket transfers imposing losses or gains on parties who would consent, if asked, to the legal imperatives in question.

${ }^{19}$ See id. at 54 .

20 "A change is said to be Pareto superior if it makes at least one person better off and no one worse off." Id. Only expressly consensual transactions can be confidently characterized as Pareto superior. 
tonomy through express consent; it rests instead upon the virtues of an attenuated vision of consent for its moral foundation. Because they are consensual, wealth-maximizing transfers both leave people wealthier and foster their sense of autonomy. And, because all wealthmaximizing transfers are consensual, they are morally justified as well.

Posner's critics, most notably Ronald Dworkin and Jules Coleman, argue that Posner has not convincingly shown that meaningful consent can be found in all three types of transactions that Posner would like to justify; he has not, the criticism goes, shown that implied or hypothetical consent are meaningful moral concepts. ${ }^{21}$ Posner unquestionably strains language and distorts reality in order to find consent in seemingly nonconsensual transactions. I will not, however, pursue that line of criticism here. Instead, I will argue that each of Posner's arguments for the morality of wealth-maximizing transfers fails for a different reason. Even assuming that meaningful consent can be found in the transactions Posner wishes to justify, Posner has not shown that the presence of consent either entails an increase in wellbeing or fosters one's sense of autonomy. Although Posner has successfully distinguished his consent-based system of morality from the utilitarian and Kantian moral traditions, he has not shown that his system captures the virtues of either. In short, he has not shown that consent is an attractive value worth encouraging in human affairs.

Franz Kafka's fictional world resembles Richard Posner's ideal world in one remarkable respect: most of what happens to Kafka's fictional characters is fully consensual, as is most of what happens to Posner's actors. Kafka's characters, like Posner's actors, consent to a wide range of legal, personal, and market transactions. First, Kafka's characters expressly consent to all sorts of humiliating and degrading commercial, employment, and sexual transactions. Second, like Posner's actors, Kafka's characters voluntarily assume risks of future losses and thereby impliedly consent to losses caused by wealth-maximizing transactions. Third, Kafka's characters, like Posner's, hypothetically consent to the authority of a wide range of nonmarket legal norms, from the norms of criminal law and procedure to the rule of law itself. As a consequence of the ever-present consent of the actors, in both worlds the distinctions between fate and choice, freedom and bondage, and power and servitude are blurred or nonexistent. Prisoners, guards, masters, slaves, criminals, and law-abiding citizens all consent to fates over which they have no control: the powerful put themselves in servitude, and slaves consent to their own bondage. For both writers, the consequence of this central paradox is that their protagonists live in a world of their own creation, but that world is, by their own choice, one which they are powerless to change.

${ }^{21}$ See Coleman, Efficiency, Utility and Wealth Maximization, 8 Horstra L. Rev. 509 (1980); Dworkin, Is Wealth a Value?, 9 J. LEGal STUd. I9I (1980). 
And yet Kafka, more than any modern writer, tells stories about victims, and Posner, more consistently than any modern theorist, defines the problem of victimization out of existence. The two writers depict the same transactions from radically divergent points of view. Kafka supplies descriptions of the internal, subjective experience of the formal transactions that Posner schematizes from his external point of view. In the internal world of Kafka's fiction, the experience of the Posnerian, rational, wealth-maximizing exchange is consistently depicted as the nightmare that follows from doing what one has consented to do.

In the three Parts below, I contrast Posner's depiction of the morally legitimating function of consent - in express consent to market transactions, in implied consent to risk, and in hypothetical consent to legal institutions - with Kafka's dramatic descriptions of the internal experiences of persons tendering each type of consent. To the extent that Kafka's descriptions ring true, they undermine Posner's normative premise that consent is morally valuable. Indeed, the power of Kafka's fiction suggests that Posner's argument rests on a severely inadequate picture of human nature and human motivation. Posner has not shown that any of the types of consent he attributes to wealth-maximizing transactions either strengthen our sense of autonomy or increase our subjective well-being. Consequently, even if wealth-maximizing transactions do meaningfully elicit consent, their moral justification has yet to be shown.

\section{The Morality of Expressly Consensual Transactions: The Thirst for PaIN, Surrender, and Humiliation}

Posner's central ethical claim is that the state of affairs resulting from an expressly consensual transaction is a moral one. ${ }^{22} \mathrm{He}$ offers two reasons. First, Posner argues, the giving of our express consent fosters our sense of autonomy, ${ }^{23}$ and expressly consensual transactions are morally praiseworthy for that reason. The second reason is more complex. Expressly consensual transactions, Posner argues, by definition increase the well-being of those who have consented. ${ }^{24}$ Relying

22 See R. POSNER, supra note I, at $48-115$.

${ }^{23} \mathrm{Id}$. at 89 .

${ }^{24}$ This argument is spread over several chapters of The Economics of Justice. In chapter three, Posner states that, under a Pareto-superior approach, a voluntary transaction with no externalities by definition increases the total amount of happiness in the world by making both parties better off than they were prior to the transaction. See id. at 54-55. In chapter four, Posner adds that, in the absence of "serious problems of monopoly and externality," such transactions also, again by definition, increase society's wealth. See id. at 79. These two claims, if true, suggest a utilitarian basis for the claim that voluntary, expressly consensual exchanges ought to be encouraged. At the end of chapter four, however, Posner promises more:

If one views wealth maximization as constrained utilitarianism (the constraint being that 
on two notoriously ambiguous passages from Bentham's Introduction to the Principles of Morals and Legislation, ${ }^{25}$ Posner asserts that individuals act so as to maximize their own pleasure and minimize their own pain. ${ }^{26}$ That, Posner explains, is what it means to "act rationally," and that is what people do. People are generally "rational maximizers of their own utility." Thus, when a purchaser pays $\$ 2$ for a tomato, he does so because he envisions greater pleasure to be had from the tomato than from other uses he might have made of the $\$ 2$. By giving up the $\$ 2$ and gaining the tomato, he has maximized his own pleasure. The seller, conversely, envisions greater pleasure from the $\$ 2$ than from the tomato. Both buyer and seller are made happier by the exchange. They both are uniquely capable of deciding which they prefer - the $\$ 2$ or the tomato - and they both are similarly motivated to allocate resources between them in such a way as to possess the resource they will most enjoy. ${ }^{27}$ Posner applies the moti-

society seeks to maximize the satisfaction only of those whose preferences are backed up by a willingness to pay), one can defend it by whatever arguments are available to defend utilitarianism; but one can do better than that, as the next chapter shows.

Id. at 87 .

In the next chapter, Posner "shows" that one can do better by demonstrating that wealthmaximization can be derived from the moral value of consensual relations. See id. at 89-96. However, the departure from consequentialist argumentation is apparent rather than real: although Posner shows that wealth maximization can be viewed as consensual, he offers nothing beyond the consequentialist argument summarized above to support the moral value of consent. A truly nonconsequentialist defense of wealth maximization would be strange: wealth maximization is, after all, a consequence of the transaction. At a minimum, such an argument would have to demonstrate the moral value of expressly consensual states of affairs independent of the consequential "well-offness" of the parties giving their consent; thus, the act of consenting itself must be shown to have moral value independent of the effect of the transaction on wealth or well-being.

25 "NATURE has placed mankind under the governance of two sovereign masters, pain and pleasure. ... They govern us in all we do, in all we say, in all we think ...." Bentham, Introduction to the Principles of Morals and Legislation, in I THE WORKS OF JEREMY BENTHAM I, I (J. Bowring ed. I843) (Ist ed. London 1789). "Men calculate, some with less exactness, indeed, some with more: but all men calculate. I would not say, that even a madman does not calculate." Id. at 90. Posner quotes these passages in R. POSNER, supra note I, at 42 .

26 "Particularly important to the approach of this book is Bentham's insistence that human beings act as rational maximizers of their satisfactions in all spheres of life, not just the narrowly economic ... ." R. POSNER, supra note 1 , at $4 \mathrm{r}-42$.

Bentham does not say, however, that all men calculate to maximize their own pleasure; he says only that all men calculate to maximize pleasure. There is strong evidence that Bentham believed that men often, if not typically, calculate so as to maximize the pleasure of their community, not just their own pleasure. See Bentham, supra note 25 , at 143-44. He clearly believed them capable of it. See id. He did not envision the "rational calculator" that Posner ascribes to him. See D. Lyons, IN THE INTEREst of The Governed: A Study in Bentham's Philosophy of UTILITY AND LAW II-18, 64-78 (I973). For a discussion of the modern positions regarding the interpretations of these passages, see West, In the Interest of the Governed: A Utilitarian Argument for Substantive Judicial Review, I8 GA. L. REV. 469, 495 n.52 (1984).

${ }^{27}$ See R. POSNER, supra note $\mathrm{I}$, at 88 . 
vations described in this narrow commercial setting to embrace all human interactions and decisions. People act so as to maximize their own utility not only when buying tomatoes on the market, but when committing crimes, ${ }^{28}$ breaching or performing contractual obligations, ${ }^{29}$ choosing a spouse, ${ }^{30}$ selecting a vocation, deciding to get up and go to work in the morning, or consenting to a sexual affair. ${ }^{31}$ There is no reason, Posner suggests, to suppose that people do not act rationally in all phases of their lives. ${ }^{32}$

Many of Franz Kafka's stories depict voluntary market transactions between expressly consenting adults. Kafka's short story "A Hunger Artist," for example, is about just such a perfectly consensual commercial transaction. ${ }^{33}$ Kafka's hunger artist is the ultimate Posnerian entrepreneur, and the artist's audience consists of Posnerian consumers. The hunger artist is a professional "faster" who presents himself at carnivals in various stages of voluntary starvation for the public's amusement, curiosity, or disgust. In this freely chosen line of work, he eventually starves himself to death:

They poked into the straw with sticks and found him in it. "Are you still fasting?" asked the overseer, "when on earth do you mean to stop?" "Forgive me, everybody," whispered the hunger artist; only the overseer, who had his ears to the bars, understood him. "Of course," said the overseer, and tapped his forehead with a finger to let the attendants know what state the man was in, "we forgive you." "I always wanted you to admire my fasting," said the hunger artist. "We do admire it," said the overseer, affably. "But you shouldn't admire it," said the hunger artist. "Well then we don't admire it," said the overseer, "but why shouldn't we admire it?" "Because I have to fast, I can't help it," said the hunger artist. "What a fellow you are," said the overseer, "and why can't you help it?" "Because . . . I couldn't find the food I liked. If I had found it, believe me, I should have made no fuss and stuffed myself like you or anyone else." These were his last words, but in his dimming eyes remained the firm though no longer proud persuasion that he was still continuing to fast. ${ }^{34}$

The carnival exhibitor consensually provides the artist with space and by so doing earns profits from the consenting and amused public, who in turn reap more pleasure from the spectacle than they surrender from the price of admission. Everyone expressly consents to the transactions and as a consequence, on Posner's assumptions, is better off

${ }^{28}$ See id. at $4 \mathrm{I}$; R. POSNER, supra note II, at $164-72$.

${ }^{29}$ See R. POSNER, supra note 11 , at $65-69$.

${ }^{30} \mathrm{See}$ id. at 104-08.

$31 \mathrm{See}$ R. POSNER, supra note I, at 237.

32 See id.

${ }^{33}$ See F. KAFKA, A Hunger Artist, in StoRIEs, supra note 9, at 268.

${ }^{34}$ Id. at $276-77$. 
and more autonomous. When the hunger artist finally wills himself - voluntarily - to death by starvation, his actions are still consensual and wealth maximizing. Because the public has grown bored with the spectacle by the time of the hunger artist's death, neither the exhibitor nor the public is made worse off by his decision. And the hunger artist continues to get exactly what he thinks he wants. "A Hunger Artist" depicts a perfectly functioning Posnerian commercial market that leaves all preferences satiated at every moment of autonomous choice.

Nevertheless, unlike the happy stories Posner tells of theoretical markets, "A Hunger Artist" is a tragic story. Unlike Posner, Kafka provides histories beyond mere "moments of choice" for our evaluation. At all times other than the moments of choice, the hunger artist is not only not better off; he is sickly, malnourished, starving, or dead. And, at all times other than the moment of decision, the hunger artist's consent does not strengthen his sense of autonomy; instead, he becomes increasingly enslaved by his obsession. The expanded time frame allows for a more complete depiction of both the hunger artist's sense of autonomy and the way in which the world has changed because of his decisions. Kafka shows the reader that, viewed over the long run, the hunger artist's consent is not "congenial" to autonomy; in a quintessentially Kafkaesque paradox, he becomes enslaved by his "thirst" for autonomy at the moment of choice. He is a consensual slave to his moment-to-moment passion for self-control, and he eventually allows that passion to destroy him.

In addition, Kafka provides his characters with motives beyond the definitionally tautological motive of wealth maximization. Like the modern anorectic, the hunger artist regards each decision not to eat as a perfectly voluntary act of self-empowerment. But also like the anorectic, the hunger artist exercises power that is followed necessarily - by the inability to free himself from the deadly consequence of that empty freedom. The hunger artist's control over his life depends upon his absolute denial of the needs and ultimately the existence of his future self; his refusal to compromise the sovereignty of his present desire for pure self-control ultimately denies the welfare - indeed the existence - of his future self. In short, he satiates his present self's preference for perfect autonomy by killing his future self. This paradigmatic Kafkaesque protagonist achieves a pure, momentary Posnerian power, but only by enslaving himself to his decision slowly to starve.

Kafka's depiction of the Posnerian reasoning behind the hunger artist's choice and the community's reaction to that choice is tragic. The community Kafka describes behaves in accordance with Posner's ideal world: the artist's subjective and actual reasons for fasting affect neither the perceived rationality of his decision nor the moral legitimacy of the community's failure to intervene. All that matters to the 
community's sense of fair play is the outward description: he fasted consensually. Motives are as irrelevant as the actual consequence of the choice. In Kafka's story, we find the community's failure to intervene morally repugnant. What in Posner's world is an expression of respect for the individual becomes in Kafka's story an instance of the community's moral failure.

Kafka's novels and stories contain other dramatic depictions of expressly consensual private transactions. Indeed, Kafka provides descriptions of the internal experience of many of the same expressly consensual transactions that Posner describes from an external, formal perspective. Both Posner and Kafka, for example, describe a consenting employee, but the images reflect drastically divergent points of view. In Posner's world, the consenting employee's sale of labor to the employer, like the consenting buyer's purchase of goods off the shelf, is wealth maximizing, conducive to autonomy, and moral because it is consensual. Even consensual enslavement, Posner insists, constitutes such a wealth-maximizing, voluntary, and thus moral sale of labor:

Suppose $A$, perhaps to provide money for his family (but the reason is unimportant), sells himself into slavery to $B$. . . From a wealthmaximization standpoint there is no economic basis for refusing to enforce [the] contract unless some element of fraud or duress is present. Nor would the economist think [the] contract so irrational as to create an irrebutable presumption that it was procured by fraud or duress or is vitiated by insanity or other incapacity. ${ }^{35}$

Kafka depicts a world of expressly consensual employment that is not so unproblematic. In Kafka's writings, expressly consensual employment not only lacks positive moral value, but it is generally portrayed as humiliating, repulsive, tragic, or fatal. In the novel The Trial, for example, the protagonist, Joseph K., discovers his warders - the men whose job it is to effect his arrest - being whipped by their superior, who is himself at the mercy of yet a higher employing authority. The consensual employment of these characters is hardly cause for moral approbation. Although the employees articulate the same reason for employment that Posner attributes to his hypothetical voluntary slave - to provide money for the family - their deeper motives reflect an urge to accept obedience and authority, not to foster their autonomy, wealth maximization, or self-improvement. The resulting world is not primarily a place in which prior preferences have been satiated - although it is that. It is not the wealthy, autonomous employment Posner depicts; instead, it is primarily a world of powerful, hierarchical relationships that are humiliating, stifling, torturous, and painful:

${ }^{35}$ R. POSNER, supra note I, at 86. 
One of the men, who was clearly in authority over the other two and took the eye first, was sheathed in a sort of dark leather garment which left his throat and a good deal of his chest and the whole of his arms bare. He made no answer. But the other two cried: "Sir! ... [A]ll is lost now . . . our careers are done for . . . and, besides that, we're in for a whipping, and that's horribly painful." "Can that birchrod cause such terrible pain?" asked K., examining the switch ... . "Well [sic] have to take off all our clothes first," said Willem. "Ah I see," said K . . . "Is there no way of getting these two off their whipping?" $K$. asked him. "No," said the man, smilingly shaking his head. "Strip," he ordered the warders. . . . The warder Franz, who ... had thus far kept as much as possible in the background, now came forward to the door clad only in his trousers, fell on his knees, and clinging to K.'s arm whispered: "If you can't get him to spare both of us, try to get me off at least. Willem is older than I am, and far less sensitive too, besides he's had a small whipping already . . . but I've never been in disgrace yet, and I was only following Willem's lead in what I did, he's my teacher, for better or worse. . . . I'm so ashamed and miserable." ... "I can't wait any longer," said the Whipper, grasping the rod with both hands and making a cut at Franz . . . Then the shriek rose from Franz's throat, single and irrevocable, it did not seem to come from a human being but from some martyred instrument .... [T] The birchrod found [Franz] where he was lying, its point swished up and down regularly as he writhed on the floor. ${ }^{36}$

K.'s own consensual employment is less brutal, but it is no less authoritarian. Although $\mathrm{K}$. suffers no physical abuse on the job, he is humiliated and dehumanized, not enriched, by his white-collar employment as Chief Clerk in a bank:

It was eleven o'clock, he had wasted two hours in dreaming, a long stretch of precious time, and he was, of course, still wearier than he had been before. ... The attendants brought in several letters and two cards from gentlemen who had been waiting a considerable time. . . . Weary of what had gone before and wearily awaiting what was to come, $\mathrm{K}$. got up to receive the first of his clients.

... [A]s [his boss, the Assistant Manager, and his client, the manufacturer,] leaned against his desk . . . it seemed to $\mathrm{K}$. as though two giants of enormous size were negotiating above his head about himself. Slowly, lifting his eyes as far as he dared, he peered up to see what they were about, then picked one of the documents from the desk at random . . . and gradually raised it, rising himself with it, to their level. In doing so he had no definite purpose . . . . The Assistant Manager . . . merely glanced at the paper without even reading what was on it, for anything that seemed important to the Chief Clerk was unimportant to him, took it from K.'s hand, said: "Thanks, I know all that already," and quietly laid it back on the desk again. K. darted 
a bitter look at him, but the Assistant Manager did not notice that, or, if he did, was only amused, he laughed loudly several times. ${ }^{37}$

Kafka's depictions of consensual sex provide a similar contrast to Posner's world. In Posner's world, consensual sex, like any other consensual transaction, should strengthen the parties' sense of autonomy, increase well-being, and render the world more moral. Yet in Kafka's fiction, consensual sexual relinquishment of control over one's sexuality rarely promotes autonomy or well-being. Instead, sexual actors are often driven by an urge to obey a person of the opposite sex who is perceived as powerful. In The Trial, for example, Joseph $\mathrm{K}$. happens upon a woman who works in the court in which he is being tried. The woman allows herself to be sexually used by her husband, by a "student of the Law Court," and by the Examining Magistrate in charge of investigating Joseph K.'s case. She explains to $\mathrm{K}$.:

"The man you saw embracing me has been persecuting me for a long time. I may not be a temptation to most men, but I am to him. There's no way of keeping him off, even my husband has grown reconciled to it now; if he isn't to lose his job he must put up with it, for that man you saw is one of the students and will probably rise to great power yet. He's always after me, he was here to-day, just before you came." 38

Later, $\mathrm{K}$. watches the student carry the woman to the Examining Magistrate, at the latter's command:

K. ran a few steps after [the student] ready to seize and if necessary to throttle him, when the woman said: "It's no use, the Examining Magistrate has sent for me, I daren't go with you; this little monster," she patted the student's face, "this little monster won't let me go." "And you don't want to be set free," cried K., laying his hand on the shoulder of the student, who snapped at it with his teeth. "No," cried the woman, pushing $\mathrm{K}$. away with both hands. "No, no, you mustn't do that, what are you thinking of ? It would be the ruin of me. Let him alone, oh, please, let him alone! He's only obeying the orders of the Examining Magistrate and carrying me to him."

... The woman waved her hand to $\mathrm{K}$. as he stood below, and shrugged her shoulders to suggest that she was not to blame for this abduction, but very little regret could be read into that dumb show. ${ }^{39}$

The woman herself expresses the motivational ambiguity latent in her submission to the Magistrate. She may, as she tells Joseph $\mathrm{K}$. in the preceding passage, tolerate the Magistrate's attentions for the

\footnotetext{
${ }^{37}$ Id. at $144-47$.

${ }^{38} \mathrm{Id}$. at $60-6 \mathrm{I}$.

39 Id. at $69-70$.
} 
welfare-maximizing reason that she needs to maintain her husband's job security. In another passage, however, she explains her attraction to this hierarchical, authoritarian relationship in very different terms:

"I didn't know that he was only a petty official, but as you say so it must naturally be true. All the same, I fancy that the reports he sends up to the higher officials have some influence. And he writes out so many reports. You say that the officials are lazy, but that certainly doesn't apply to all of them, particularly to the Examining Magistrate, he's always writing. Last Sunday, for instance, the session lasted till late in the evening. All the others left, but the Examining Magistrate stayed on in the courtroom, I had to bring a lamp for him, I only had a small kitchen lamp, but that was all he needed and he began to write straight away. . . . Suddenly, in the middle of the night ... I woke up, the Examining Magistrate was standing beside our bed shielding the lamp with his hand to keep the light from falling on my husband .... I was so startled that I almost cried out, but the Examining Magistrate was very kind, warned me to be careful, whispered to me that he had been writing till then, that he had come to return the lamp, and that he would never forget the picture I had made lying asleep in bed. I only tell you this to show that the Examining Magistrate is kept really busy writing reports .... Such long reports as that surely can't be quite unimportant. ... And by this time I have other proofs that he is anxious to win my favor. Yesterday he sent me a pair of silk stockings ... . They're beautiful stockings, look" - she stretched out her legs, pulled her skirts above her knees, and herself contemplated the stockings - "they're beautiful stockings, but too fine, all the same, and not suitable for a woman like me."40

In Posner's world, reasons for consent are strictly irrelevant: expressly consensual transactions by definition promote both autonomy and well-being. In Kafka's sexual world, reasons are not irrelevant, but they are maddeningly ambiguous: for every sexual transfer that Kafka describes, he provides a conventional, welfare-maximizing motive (often spoken by the victim) for the consent, along with overwhelming evidence that the truer motive is submission to the power of male authority. The woman in the law court says that she grants access to her body for welfare-maximizing reasons: either in exchange for her husband's job security or for sexual pleasures of her own. Alternatively, however, she may consent to the transactions because she is attracted to the Examining Magistrate's power and authority. For her, as for Kafka's characters generally, the sexual act is consensual and in some sense satisfying. In no case, however, is the resulting transaction portrayed as conducive to autonomy or individual wellbeing, and in no case is the resulting state of affairs portrayed as

${ }^{40}$ Id. at $64-66$. 
moral. The sexual transfers, like the consensual enslavements, are repulsive and perceived as such by the reader, if not by the participants themselves.

In all of these market transactions - commercial, employment, and sexual - Kafka portrays one party consenting to a transfer of power over that party's body, and in each instance the transfer, although consensual, is horrifying. In none of Kafka's depictions does consent entail an increase in well-being. The hunger artist's welfare is not improved by his decision; he starves. The warders' welfare is not increased by their endurance of whippings; they are humiliated and pained. The woman in the law court is not enlivened by her multiple sexual encounters; she is dehumanized. Nor do these consensual transactions leave the parties more autonomous than before the transfer. The participants are often motivated by a desire to submit to authority, not to enhance autonomy, and in each case, the authoritarian relationship they create proves to be a damaging one. The hunger artist's bondage to his own tyrannical whim destroys him; the warders' acquiescence to the whipper's sadism further enslaves them; and the woman's sexual submission to the Magistrate weakens her. Each of these expressly consensual transactions strengthens a belittling, humiliating, and sometimes fatal relationship.

Kafka's depictions of commercial, employment, and sexual transactions illustrate a simple truth: the consensual bargain that underlies commerce, labor, and sex may save those transactions from being theft, slavery, or rape, but it hardly accords them positive moral value. Consensual acts of commerce, labor, or sexual intercourse are not morally good simply because they are not coerced: a bad trade is still bad, even if it is not theft; a bad job is still bad, even if it is not slavery; and bad sex is still bad, even if it is not rape. The morality of any of these consensual transactions depends upon the value of the worlds they create, which in turn depends in part upon the worth of the relationships they contain. A sexual transaction between an authoritarian employer and a submissive woman does not typically create a morally good relationship, even if it is not rape. The consensual contract between a sadistic employer and a submissive employee is not a morally good relationship, even if the employee would have worked for less. Relationships such as these are harmful for both the submissive and the dominant party. It is immoral to participate in such consensual transactions and immoral for the community to tolerate them.

If Kafka's descriptions of consensual transactions reveal a truth about the complexity of human motivations, Posner's claim that express consent reinforces one's sense of autonomy and by definition maximizes one's well-being is simply untenable. It does not follow from the definition of consent that people consent to what they think will make them better off, what will in fact make them better off, 
what they think will enlarge their freedom, or what in fact will do so. If it follows from the fact of consent that relationships or transactions to which we have consented strengthen our sense of autonomy or leave us better off, they do so by virtue of our human motivations and capabilities. At best, then, it is only contingently and not analytically true that expressly consensual states of affairs are congenial to autonomy or that they maximize the well-being of those who consent.

Posner's definitional claims that consent both promotes autonomy and triggers an increase in well-being hide the need for an empirical argument. The latter definitional claim depends upon two distinct empirical premises. The claim that we choose what maximizes our well-being depends, first, on our being capable of preferring and choosing that which will leave us best off and, second, on our being motivated to prefer and choose that which will leave us better off. Both of these claims are contestable. As other critics of the law-andeconomics tradition have shown, we have good reasons (such as lack of information, duress, or addictive preferences) ${ }^{41}$ for distrusting our ability to maximize our own well-being through choice. We ought also, however, to be skeptical of our motivation to increase our wellbeing through choice. Even an actor fully capable of improving his well-being through market and interpersonal transactions may choose a state of affairs that leaves him worse off because he is motivationally disinclined to improve his well-being through consensual transactions. If our reasons for consenting to changes in our worlds are varied, then the automatic equation of the fact of consent to change and either an attempted or an actual increase in well-being is specious.

Posner's other definitional claim - that consensual transactions promote autonomy - fails for a similar reason. We may consent to a transaction not to foster our autonomy, but rather solely to please or defer to a perceived authority. Whether or not the resulting transaction promotes autonomy depends on the authoritarian relationship thereby created. Some such relationships promote autonomy. Many, however, do not.

Moral assessment of a change in resource allocation depends on a rich, full description of the changed world. If the transaction to which we have consented involves only an increase in our own wellbeing, then the assessment of the moral value of the post-transaction world can focus solely on that increase. The trade may indeed both promote autonomy and increase well-being. But if the trade is for one or both parties not an act of welfare betterment, but an act of submission to an authority, then the post-transaction world includes a newly created or strengthened hierarchical relationship. If so, the

${ }^{41}$ See, e.g., Kelman, Choice and Utility, I979 WIS. L. REv. 769. 
moral value of the resource reallocation also depends upon the moral value of that change in the world. The theorist must evaluate the consequences of that change - whether, by obeying, we have submitted to a valuable authoritarian relationship that will foster our autonomy and help us grow, or whether we have succumbed to an exploitative relationship that will damage or destroy us.

An accurate identification of our motives for acting is a necessary, but not a sufficient, component of a moral evaluation of the worlds that our consensual acts create. Just as there is no automatic equivalency between consent and egoistic motivation, there is no definitional correlation between any particular motivation or set of motivations and good or evil. If a purchaser buys a tomato for $\$ 2$ in order to increase her own well-being, she may or may not create a better world in the process. If she likes tomatoes and uses them as part of a nutritional diet, she very likely has increased her well-being by the purchase. If, on a daily basis, she buys twelve tomatoes, eats five plates of spaghetti, and regurgitates it all, thus destroying her digestive tract as surely as an alcoholic destroys his liver, then the purchase of the tomatoes has not maximized her well-being, regardless of what she would have paid for them and regardless of the resultant consumer surplus.

Alternatively, if the purchaser buys the tomato not to increase her own welfare, but because she has been told to do so, again, she may or may not have thereby created a morally better world. The hierarchical relationship she has furthered may be either good or bad for the parties involved. Hierarchical relationships can strengthen our autonomy and leave us better off if they help us grow, develop talents, improve our mental health, our physical health, our store of knowledge, or our wisdom. They weaken us and leave us worse off if they render us dependent on an unreliable or untrustworthy source of information, if they divest us of the power to engage in essential human activities, or if they deprive us of self-respect or the ability to make independent moral judgments. In the case of the tomato purchase, it is not hard to imagine a desirable world in which we reasonably rely upon the benign and informed authoritative guidance of others on questions of health and diet - perhaps we live in such a world. Our diet is improved if the authority we trust has superior competence, our time is freed to be spent on other concerns, and our faith in the good intentions and competence of other members of our community is strengthened by their successful regulation of this aspect of our lives. Yet one can also easily envision an over-regulated, authoritarian nightmare in which our health, as well as other aspects of our private lives, is strictly controlled by others. We might find ourselves eating plastic-textured tomatoes, estranged from the natural processes of planting, harvesting, and managing vegetables, ignorant of our biological and nutritional needs, and ultimately enslaved by 
our dependence on the dubious authority of unknown others. Women suffering from bulimia, anorexia, and related dietary disorders may be living in just such an excessively authoritarian and nightmarish world. Whether the world, including our own world, is better or worse because of our decisions to buy tomatoes because we have been told to purchase them, and whether our autonomy is strengthened or depleted, depends upon the nature and moral quality of this authoritarian relationship.

Our natural inclination to follow the advice or command of perceived and actual authorities is no more intrinsically bad than our self-interested and autonomous inclinations, lauded by the law-andeconomics school, are intrinsically good. ${ }^{42}$ Inclinations toward obedience and submission to authority unquestionably have good effects - one of which is that they make possible the development of the egoistic, autonomous self that is of such concern to the law-andeconomics school. It would be difficult or impossible to become meaningfully autonomous if we were not inclined to subordinate our own will to the dominant will of someone we trust or respect. For example, it would be hard to learn to play the piano if we had to reassess on our own the merit of playing scales with every practice session, and it would be hard to achieve personal intimacy if we derived no pleasure or satisfaction from the voluntary act of submission. Growth itself, whether psychological, cognitive, artistic, or emotional, depends upon our ability to submerge our spontaneous will at least as much as it depends upon our ability to assert it. It would be impossible for the present self to give way to a future, happier, more productive self if it were not motivationally inclined on occasion to deny itself or submit to the will of others.

There are, then, good prudential reasons for furthering the greater happiness of a future self over the momentary pleasures of the present

42 Posner's insistence that the wealth-maximizing decision is the morally correct decision is manifest throughout The Economics of Justice. Thus, Posner not only views the wealthy thief as morally superior to the impoverished thief, see R. POSNER, supra note 1 , at $62-63$, and the wealthy purchaser as more moral than the impoverished thief, see id. at 66 , but he also views the wealth-maximizing producer as morally superior to the wealthy philanthropist:

Most of the conventional pieties - keeping promises, telling the truth, and the like can also be derived from the wealth-maximization principle. Adherence to these virtues facilitates transactions and so promotes trade and hence wealth by reducing the costs of policing markets through self-protection, detailed contracts, litigation, and so on. Even altruism (benevolence) is an economizing principle, because it can be a substitute for costly market and legal processes. And yet even the altruist might decide to sell his services to the highest bidder rather than donate them to the neediest supplicant. Because of the costs of determining need other than through willingness to pay, allocation by price may confer greater net benefits on the rest of society than allocation by "need" or "desert." Allocation by price will also result in a greater accumulation of wealth. This wealth can be given away in whole or in part - though again the altruist will not want to spend so much time screening applicants for charity that he greatly reduces his productive work and the benefits it confers on other people.

Id. at 67-68 (emphasis added) (footnotes omitted). 
self by subordinating the latter to the will of others. But inclinations toward obedience and submission also make possible a wide range of structures, communities, and relationships of social and moral, not just prudential, value. Religious callings clearly depend upon the human urge to submit to and serve higher authority. Our major moral traditions also rely upon authoritarian urges: to behave morally is, centrally, to submit to the authority of higher rules of moral conduct - duties imposed upon us by force of those rules, Kant's formulation of the "categorical imperative," or the utilitarian mandate to contribute to the community's happiness. Furthermore, we often regard a morally submissive attitude as exemplary of virtue: the obedience of the foot soldier in a just war or of a monk in a Benedictine monastery is regarded by some, at least, as morally exemplary. The soldier who dies in battle while unflinchingly obeying a superior does not exhibit the same virtue as the soldier who hurls himself on the live grenade of his own accord, but he certainly makes the same sacrifice. The ability to submit to a duty or to a moral rule is as necessary a part of moral conduct and of religious life as the ability to determine individually, independently, and rationally the rule one ought follow. ${ }^{43}$

On the other hand, our authoritarian instincts have tremendously destructive potential. When we willingly relinquish too much control over ourselves or our environment, we risk losing our "selves" altogether to the wills of others. When we regularly submit to rules and directives of others, we become less practiced at assessing the moral, social, or prudential aspects of a particular situation - our own or any other. A learned habit of impotence can be as addictive, as attractive, and ultimately as dangerous as a learned preference for heroin, or, for that matter, as the thirst for power. The easy freedom from responsibility that follows from the misperception that one is not able to change one's situation can imprison us in destructive and damaging work environments, career ruts, marriages, home lives, and sexual relationships. It can seduce us into the legitimating, comfortable belief that the ruler we have submitted to, whether retailer, employer, or lover, is omniscient when he is in fact ignorant or misinformed; that he is moral when he is in fact corrupt; that he is acting in our interest when he is in fact acting in his own; or that he is leading us toward the shining City on the Hill when he is leading us toward disaster. The dangers latent in our need for obedience and submission should not be understated: when the authoritarian relationship is a bad one, at best we lose a measure of self-respect and the pleasures that come from true autonomy; at worst we become dehumanized automatons hypersensitive to authoritarian suggestion

${ }^{43}$ See generally Werkmeister, The Function and Limits of Moral Authority, in AUTHORITY: A Philosophical analysis 94 (R. Harris ed. 1976). 
and a danger to ourselves and others. But we do not avert these dangers by denying the human motivation within us that renders these phenomena possible. Nor, for that matter, do we avert them by denying the positive and valuable social relations the same motivation facilitates.

\section{The Morality of Impliedly Consensual Transactions:}

\section{The AtTraction of the Risk of Loneliness and Death}

Although the Pareto morality of expressly consensual transactions constitutes Posner's ethical ideal, ${ }^{44}$ he willingly concedes that only a small subset of the wealth-maximizing transfers he wishes to justify have been expressly consented to by all affected parties. ${ }^{45}$ Most wealth-maximizing transactions have both intentional and unintentional effects on third parties who have not expressly consented to the transaction. Such transactions cannot be justified by reference to express consent and the automatic increase in well-being that such consent definitionally entails. ${ }^{46}$ Nor can they be justified with a utilitarian calculus if we insist, as Posner does, upon the incomparability of subjective utility values. ${ }^{47}$ Society is, of course, collectively wealthier if the transaction is wealth-maximizing, but there may nevertheless be a loser; therefore, we cannot infer that the transaction has increased the collective well-being - as opposed to the wealth - of the community. The loss as felt by the loser may outweigh the gains experienced by the winners. ${ }^{48}$

Nevertheless, Posner argues, in "[m]any" of these cases, the losing parties have impliedly consented to the wealth-maximizing transaction. ${ }^{49}$ "The version of consent used here," Posner writes, "is ex ante compensation." 50 By "ex ante compensation," Posner does not mean that the losing parties received beforehand a benefit equal to the full value of the loss subsequently suffered. Instead, in an earlier transaction, the eventual loser received some benefit in exchange for the voluntary decision to assume the risk of the subsequent loss.

Posner gives two examples to demonstrate the operation of ex ante compensation. In the first, a plant relocates from one town to another, causing a loss for surrounding landowners. The move is by hypothesis wealth maximizing: "The plant owners are better off, and the pecu-

\footnotetext{
44 See R. Posner, supra note $\mathrm{I}$, at 88-90.

45 See id. at 88-89, 94-97.

${ }^{46}$ See id. at 88-90.

${ }^{47}$ See supra p. 389.

48 See R. POSNER, supra note $\mathrm{r}$, at $9 \mathrm{I}$.

${ }^{49} \mathrm{See}$ id. at 94 .

${ }^{50} \mathrm{Id}$.
} 
niary externalities cancel out."51 In the second example, an entrepreneur suffers losses as a result of the entrance of a more successful product into the market. In both cases, "the wealth-maximization criterion ... would allow the move," 52 yet in neither case have the losers expressly consented to the event that causes their loss. In neither case, Posner states, is there any way of knowing whether "the utility to the winners . . . exceeds the disutility to the losers." 53

According to Posner, however, in both cases the losing parties assumed the risk of the loss that eventually befell them. Both losers impliedly consented to the loss, and the wealth-maximizing transaction is accordingly justified:

Since the entrepreneur's expected return includes a premium to cover the risk of losses due to competition, he was compensated for the loss ex ante. . . [T] [Te landowners [were compensated in this manner] at the time they bought the land: the probability that the plant would move was discounted in the purchase price they paid. ${ }^{54}$

Posner employs a metaphor to illustrate the manner in which the ex ante compensation of the landowner and of the entrepreneur can be viewed as a proxy for their implied consent. The consent, Posner suggests, is similar to the consent of the loser of a lottery to the loss of the cost of the ticket:

It is my contention that a person who buys a lottery ticket and then loses the lottery has "consented" to the loss so long as there is no question of fraud or duress; at least he has waived any objection to the outcome, assuming there was no fraud in the lottery. ${ }^{55}$

The landowner and the entrepreneur similarly buy a "lottery ticket" in buying land or going into business. Because the parties bargain for a "bundle" of benefit-plus-risk, by definition it leaves them better off than would alternative uses of resources to which they could have consented. In exchange for shouldering the particular risks involved in their purchases, they receive a value greater than the cost of all of the possible results discounted by the probability of their occurrence. That one of those assumed risks eventually comes to pass does not change the result. Therefore, according to Posner, even an eventual loser in the wealth-maximizing transaction is made wealthier by the consensual assumption of the risk, because he voluntarily bargains for the risk of the loss he eventually sustains. And of course, even

Si Id. at $9 \mathrm{I}$.

52 Id.

53 Id.

54 Id. at 94 .

ss Id. 
eventual losers strengthen their sense of autonomy; they choose to enter the risk-allocation lottery.

Kafka provides several examples of failed entrepreneurs who have consented ex ante to the loss they suffer ex post in just the manner Posner describes. Kafka's entrepreneurs, like Posner's, are compensated during their early successful days for the risk of the losses that subsequently befall them. Like Posner's actors, these businessmen voluntarily assume the risk of the failure they ultimately suffer. Again, "A Hunger Artist" is the classic text. Kafka's hunger artist voluntarily chooses his profession and therefore voluntarily assumes the risks the path entailed. $\mathrm{He}$ is compensated, ex ante, for the risk that events beyond his control would some day render his art out of vogue - that some day he would fail to inspire or even draw an audience:

During these last decades the interest in professional fasting has markedly diminished. It used to pay very well to stage such great performances under one's own management, but today that is quite impossible. We live in a different world now. At one time the whole town took a lively interest in the hunger artist; from day to day of his fast the excitement mounted; everybody wanted to see him at least once a day; there were people who bought season tickets for the last few days and sat from morning till night in front of his small barred cage . . .

A few years later when the witnesses of such scenes called them to mind, they often failed to understand themselves at all. For meanwhile the aforementioned change in public interest had set in; it seemed to happen almost overnight; there may have been profound causes for it, but who was going to bother about that; at any rate the pampered hunger artist suddenly found himself deserted one fine day by the amusement-seekers, who went streaming past him to other more-favored attractions. ${ }^{56}$

The hunger artist reacts to his situation as Posner would expect: he moves to a new position.

Fasting would surely come into fashion again at some future date, yet that was no comfort for those living in the present. What, then, was the hunger artist to do? He had been applauded by thousands in his time and could hardly come down to showing himself in a street booth at village fairs, and as for adopting another profession, he was not only too old for that but too fanatically devoted to fasting. So he ... hired himself to a large circus; in order to spare his own feelings he avoided reading the conditions of his contract. 57 
The hunger artist again voluntarily assumes risks, including the risk of unread contract terms. The hunger artist is compensated ex ante: his fanatical devotion to fasting compensates for the assumed risk of desertion by his public, while his "spare[d] . . . feelings" compensate for the assumed risk of unknown employment conditions.

In the short story "The Judgment," 58 Kafka contrasts a failed entrepreneurs's implied consent to the risk of failure with a successful entrepreneur's more fortunate spin of the wheel. Kafka allows the reader to view the failed entrepreneur's situation from the more successful protagonist's point of view:

He was thinking about his friend, who had actually run away to Russia some years before, being dissatisfied with his prospects at home. Now he was carrying on a business in St. Petersburg, which had flourished to begin with but had long been going downhill, as he always complained on his increasingly rare visits. So he was wearing himself out to no purpose in a foreign country, the unfamiliar full beard he wore did not quite conceal the face Georg had known so well since childhood, and his skin was growing so yellow as to indicate some latent disease. By his own account he had no regular connection with the colony of his fellow countrymen out there and almost no social intercourse with Russian families, so that he was resigning himself to becoming a permanent bachelor. ${ }^{59}$

\section{The reader next learns of the protagonist's contrasting fate:}

But during these three years Georg's own position in life had changed a lot. Two years ago his mother had died, since when he and his father had shared the household together .... Since that time, however, Georg had applied himself with greater determination to the business as well as to everything else.

Perhaps during his mother's lifetime his father's insistence on having everything his own way in the business had hindered him from developing any real activity of his own, perhaps since her death his father had become less aggressive, although he was still active in the business, perhaps it was mostly due to an accidental run of good fortune - which was very probable indeed - but at any rate during those two years the business had developed in a most unexpected way, the staff had had to be doubled, the turnover was five times as great; no doubt about it, further progress lay just ahead. ${ }^{60}$

Kafka's failed businessmen, unlike Posner's, neither gain in wellbeing nor enhance their sense of autonomy by deciding to enter the market. The hunger artist's professional choice confines him to a cage, where he depends upon the fickle interest of the consuming public

\footnotetext{
5s F. KAFKA, The Judgment, in STORIES, supra note 9, at 77.

59 Id.

${ }^{60} \mathrm{Id}$. at $78-79$.
} 
and ultimately is enslaved and killed by his own passions. The consensual decision of Georg's friend places him in the "vastness of Russia," alienated from friendship and community, and expatriated from native soil. Both entrepreneurs become trapped by their business ventures, not freed. By choosing to starve or by choosing to run away to a foreign land, these entrepreneurs consensually alienate their autonomy to the authority of fate. Their choices reflect despair, not triumph. Kafka's depictions of unsuccessful entrepreneurs, formally so similar to Posner's risk-taking entrepreneurs and landowners, dramatize the failure of community, not the victory of the autonomous individual.

Nor is the well-being of the hunger artist or Georg's friend in any meaningful sense increased by the chance for success or the premium of gain received during their early success. Their subsequent loss, discounted by the risk of its occurrence, is simply not compensated ex post by their early success or the chance for success initially purchased. The hunger artist himself expresses the point; he knows that he has been abandoned by his fickle public and not compensated either ex post or ex ante for his eventual failure:

[T] ]he artist simply fasted on and on, as he had once dreamed of doing, and it was no trouble to him, just as he had always foretold, but no one counted the days, no one ... knew what records he was already breaking, and his heart grew heavy. And when once in a while some leisurely passer-by stopped, made merry over the old figure on the board, and spoke of swindling, that was in its way the stupidest lie ever invented by indifference and inborn malice, since it was not the hunger artist who was cheating, he was working honestly, but the world was cheating him of his reward. ${ }^{61}$

The failure of Georg's friend is similarly uncompensated, either ex post or ex ante. In a moment of pained self-enlightenment, Georg perceives this truth clearly:

His friend in St. Petersburg ... touched his imagination as never before. Lost in the vastness of Russia he saw him. At the door of an empty, plundered warehouse he saw him. Among the wreckage of his showcases, the slashed remnants of his wares, the falling gas brackets, he was just standing up. Why did he have to go so far away! 62

If the entrepreneurial opportunities our market system provides are truly like lottery tickets, as Posner's example suggests, then the fact that the system produces wealth-maximizing winners who increase the size of the pie does indeed entail that there will be losers as well

61 F. KAFKA, A Hunger Artist, in SToRIEs, supra note 9, at 276.

62 F. KAFKA, The Judgment, in STORIEs, supra note 9, at 85. 
and that those losers will suffer. Posner teaches us that when the risk of a loss is voluntarily assumed, the ultimate suffering of that loss is consensual and we consequently need concern ourselves no more with losers in the market than with those in a lottery. Kafka's stories tell a different tale. In Kafka's stories, the community's refusal to intervene and come to the aid of the market's losers is revealed as a breakdown of community and brotherhood, not a legitimate response to a morally satisfactory state of affairs. The human attraction to winners and revulsion toward losers do not serve as reliable guides to moral conduct, but instead carry the seeds of tragedy.

Thus, in "A Hunger Artist," the cage left empty by the artist's death is filled by a young panther, to the community's immense relief and satisfaction. The community much prefers the panther's strength, his successful conquest of life, to the hunger artist's failed attempt to stay alive while starving. Yet we find the community's attraction to the winner unnerving. The attraction to the panther's success is depicted to be as inhuman and immoral as the community's earlier distaste for the hunger artist's self-imposed death. Indeed, the community is as incapable of recognizing the panther's bondage as it was earlier incapable of responding to the hunger artist's despair:

"Well, clear this out now!" said the overseer, and they buried the
hunger artist, straw and all. Into the cage they put a young panther.
Even the most insensitive felt it refreshing to see this wild creature
leaping around the cage that had so long been dreary. The panther
was all right. The food he liked was brought him without hesitation
by the attendants; he seemed not even to miss his freedom; his noble
body . . . seemed to carry freedom around with it too; . . . and the
joy of life streamed with such ardent passion from his throat that for
the onlookers it was not easy to stand the shock of it. But they braced
themselves, crowded around the cage, and did not want ever to move
away. ${ }^{63}$

Similarly, in "The Judgment," Kafka portrays Georg's failure to come to the aid of his failed friend not as a legitimate response to a morally satisfactory state of affairs, but as a thinly rationalized, selfserving abandonment of friendship:

What could one write to such a man, who had obviously run off the rails, a man one could be sorry for but could not help. Should one advise him to come home, to transplant himself and take up his old friendships again - there was nothing to hinder him - and in general to rely on the help of his friends? But that was as good as telling him, and the more kindly the more offensively, that all his efforts hitherto had miscarried, that he should finally give up, come back home, and be gaped at by everyone as a returned prodigal, that 
only his friends knew what was what and that he himself was just a big child who should do what his successful and home-keeping friends prescribed. And was it certain, besides, that all the pain one would have to inflict on him would achieve its object? Perhaps it would not even be possible to get him to come home at all - he said himself that he was now out of touch with commerce in his native country - and then he would still be left an alien in a foreign land embittered by his friends' advice and more than ever estranged from them. But if he did follow their advice and then didn't fit in at home - not out of malice, of course, but through force of circumstances - couldn't get on with his friends or without them, felt humiliated, couldn't be said to have either friends or a country of his own any longer, wouldn't it have been better for him to stay abroad just as he was? Taking all this into account, how could one be sure that he would make a success of life at home? 64

There is ultimately no way, Georg concludes, to tender aid and comfort to his failed friend. Consequently, he reasons, he should refrain from pointing out to his friend the difference between his own extraordinarily lucky roll of the dice - both in business and in romance - and the less fortunate experience of his friend. On the contrary, those differences should be minimized, trivialized, or ignored. Georg thereby renders himself incapable not only of caring for a friend in need, but also of the intimacy of friendship:

For such reasons, supposing one wanted to keep up correspondence with him, one could not send him any real news such as could frankly be told to the most distant acquaintance. It was more than three years since his last visit, and for this he offered the lame excuse that the political situation in Russia was too uncertain ....

So Georg confined himself to giving his friend unimportant items of gossip such as rise at random in the memory when one is idly thinking things over on a quiet Sunday. ${ }^{65}$

Again, Kafka's stories illustrate a simple truth: to say that the risk of a loss is consensually assumed is not to imply that the subsequent "ownership" of a set of risks promotes either one's well-being or one's sense of autonomy. Nor does the loser's consent insulate community and friends from a moral obligation to relieve the impact of personal tragedy or to ease suffering. It may be natural to love winners and strong panthers, but it is morally inexcusable to dismiss losers on the basis of a facile judgment that they consented to play the game. When Georg faces the true magnitude of his friend's suffering and his own self-imposed alienation from that suffering, he is driven to such guilt and despair that he ultimately feels compelled to carry out his own

64 F. KAFKA, The Judgment, in STORIEs, supra note 9, at 77-78.

65 Id. at $78-79$. 
death sentence. The cost of Georg's self-knowledge - guilt, a death sentence, and suicide - is grotesque, but the lesson itself is not. Excusing one's own inhumanity by protecting the freedom of the loser to suffer is revealed as a type of sin.

If we grant Posner's normative assumption that any consensual state of affairs is moral because of the fact of consent, then his conclusion that consensually assumed risk is moral readily follows. ${ }^{66}$ If consensual transactions necessarily promote one's sense of autonomy and increase well-being - thus leaving the world a morally superior place - then there is no reason to believe that the world is not improved just as much by consensual allocations of risk as by consensual allocations of tangible resources. The problem with Posner's argument is that even if these losses have been impliedly consented to, he has not shown that anything of moral significance follows from that fact. Posner has not shown that implied consent to a risk of loss morally validates our failure to compensate losers. Nor has he shown that consent to a risk of loss renders the world containing the risked loss morally superior to the world that preceded the allocation of risk.

Posner's lottery analogy demonstrates the poverty of his argument. Nothing illustrates more dramatically the moral insufficiency of consent to risk-taking than a lottery. Because Posner assumes that any consensual market transaction by definition strengthens autonomy and increases the well-being of the consenting party, he never asks whether the purchase of risks and chances strengthens autonomy or increases the well-being of contingent, particular risk-buyers. Yet it seems clear that whereas such purchases improve the world for some people, they do not for others. As with the expressly consenting tomato buyer, a risk-buyer may fail to increase his well-being for any number of reasons. The preference for the risks and chances associated with the purchase of a lottery ticket may reflect misinformation or a lack of information; it may, for example, register an exaggerated belief in the buyer's control over fate. But more fundamentally, it also seems clear that for vast numbers of people, the purchase of risk and chance results not in reenforcement of personal autonomy, but in disastrous deterioration of that important human value.

In fact, Posner's lottery example highlights the gross disjunction between consensual acceptance of risk and the autonomous values

${ }^{66}$ This argument about assumed risk serves only, of course, to justify transactions to which eventual losers have at some earlier point given their implied consent. In a footnote, Posner indicates his willingness to extend the conclusion beyond these parameters:

[The] argument[] . . resemble[s] a position taken by many welfare economists: that the

Kaldor-Hicks criterion for deciding whether to undertake a public project satisfies the

Pareto-superiority criterion provided there is a sufficient probability that an individual will benefit in the long run from such projects, though he may be a loser from a particular one.

R. POSNER, supra note I, at 94 n.I8. 
that consent purportedly promotes. Even assuming that the bettor is fully informed of the risk and fully cognizant of alternative uses of his money, the purchase of a particular bundle of risks may result from a compelling or compulsive urge to relinquish control over his future. Regardless of one's definition of well-being, assumption of risk is the very antithesis of autonomy when it entails abandonment, not enrichment, of personal responsibility. The frequenter of a homosexual bathhouse who engages in indiscriminate and dangerous sex, for example, may be consciously assuming the risk of contracting AIDS, but in some cases that risk-preference may register the depth of that consumer's compulsive attraction to the risk of death, not the height of his risk-taking lust for life. Assumption of that risk neither leaves the bathhouse customer better off nor furthers his autonomy, no matter what price he would have paid for admission, and no matter what the consumer surplus. ${ }^{67}$ The European libertines who accepted bundles of consensual sex and high risks of death during the outbreak of syphilis in the sixteenth century may have been similarly motivated. The bathhouse customer, like the sixteenth-century libertine, may experience his preference not as a rational response to his own level of risk-affinity and desire for consensual sex, but as an intense relinquishment of responsibility for his own life and well-being.

The innocuous purchase of a lottery ticket might also reflect not the buyer's attraction to risk, but instead the buyer's preference that fate govern his fortune over alternative uses of resources that would enhance his ability to control his own future. Although the purchase is consensual, what the purchaser may be buying is not a reallocated bundle of risks of loss and chances for fortune, but instead his own submission to a post-bet world governed by the authority of luck. No matter what the odds, and no matter how well-informed a buyer so motivated, the purchase is an act of submission, not an act that enhances autonomy. Indeed, the pleasure of submitting one's fate to the spin of the wheel - the authority of luck — is often precisely what the casual and occasional bettor buys. When we bet we give full reign to our impulse to abandon the pursuit of autonomy and submit instead to forces outside of our control. No authority is as absolute, or as blind to individuating circumstance, as luck. Like the urge to submit to the dictates of personal authority, the inclination to submit to the authority of fate may manifest a relinquishment, not an enrichment, of autonomy.

${ }^{67}$ The San Francisco bathhouses - defined by one authority as "sex establishments where men engage in ... high-volume, high-frequency sex" - were closed by the San Francisco Director of Public Health in October I984. See Leishman, San Francisco: A Crisis in Public Health, The ATLANTIC, Oct. 1985, at 28. As of October 1985, San Francisco was the only city to close its bathhouses. The San Francisco gay community was and remains divided over the closing of the baths. For a history of the closing of the baths and a full discussion of other actions San Francisco has taken or considered taking to control the AIDS crisis, see id. 
When an individual is motivated by the inclination to submit to the authority of fate, the purchase of risk constitutes consensual control over one's future in only the most superficial of ways. In a narrow sense, the bettor - like the hunger artist - is in complete control of his future; he consciously decides whether or not to consent to proffered odds. But that total control is manifested in a decision to relinquish control over one's own creation of future selves. In the most literal sense the bettor puts his faith in a higher authority random fate - and abandons his own attempt to create a meaningful future for himself. No single consensual act stands in more striking contrast to the rich meaning of personal autonomy - the phenomenon of personal empowerment, the ability to change one's own world and social world for the better, and the possession of faith in one's powers - advocated by John Stuart Mill and Adam Smith.

An assessment of the moral value of a post-bet world, then, must begin with an accurate description of the world and the transaction that brought it into being. If the purchase of the risk was a consensual relinquishment of personal autonomy to the authority of luck, then the value of the post-bet world must include a valuation of that changed relationship, and not simply an examination of changed odds. It is not inevitably damaging to oneself to assume risks, buy chances, or gamble. An occasional bet makes for a happier world. Betting is probably more fun when it is a relinquishment of responsibility for consequences, once the purchase is made, than when it is simply the purchase of preferred risks. The experience of submission in a controlled and limited context is exhilarating and entertaining. But the relationship between the authority of luck and a submissive bettor is often destructive. The danger of addictive gambling lies in the very fact that it is such an easy release for our impulse to abandon control over the future. When the consensual relationship between authoritarian fate and a bettor is a bad one, the consequences are devastating. The human tragedies caused by compulsive gambling testify to the danger inherent in our natural propensity to submit. We are right to be wary of our enjoyment of gambling and to urge restraint of the inclination to buy risks of loss and chances for fortune.

In the entrepreneurial context as well, risk-taking may or may not be antithetical to the ideal of personal autonomy. When the entrepreneur goes into business for herself, she may be doing so because, unlike either the compulsive or casual bettor, she has faith in her ability to carve her own future and her own contribution. She may also, like the bettor, be attracted to the prospect of the gamble that entrepreneurship represents. But our admiration of the courage or pluck of the individual entrepreneur stems from our belief that most entrepreneurs are drawn to their projects by the urge to be masters of their own fate. Entrepreneurship is at best creative and selfaffirming. The entrepreneur we admire unquestionably takes risks, 
but she takes them because of her faith in her own ability to overcome them, not because the odds are more attractive than her own creative powers. The landowner that we admire buys land to use it productively in a manner that will afford him a degree of control over his fate and his contribution. The speculating landowner, by contrast, is only tolerated, not admired; he does not represent our moral ideal of the social value gained from the individual ownership of property.

Posner's lottery metaphor, far from explaining why consensually assumed risks of loss definitionally entail a morally superior world, illustrates the radical contingency of that implication. The assumption of risk and the purchase of chance can, but often do not, manifest motivations that we rightly admire - self-control, faith in one's own abilities, productive and creative use of one's environment. At other times, assumption of risk manifests an urge to relinquish control over one's future. At worst, it manifests total lack of control over oneself and the world. The preference revealed by such a purchase expresses the belief that luck will deal a better hand than we can create for ourselves. As such, it reveals the measure of our self-contempt, not the measure of our individual greatness, and in every way conceivable contradicts the ideal of self-respect and autonomy that Posner purports to celebrate in consent.

If one can morally justify our refusal to compensate the losses suffered by Posner's failed entrepreneur, the disappointed landowner, the bathhouse frequenter who contracts AIDS, the sixteenth-century libertine who contracts syphilis, the hunger artist, or Georg's expatriated friend, the reason must be other than the resemblance of any of these individuals to the consensual gambler. There may be no good reason to compensate unsuccessful gamblers beyond what they receive ex ante, but that is not because we find the post-bet world morally superior to the pre-bet world. The purchase of a lottery ticket is not an example of a consensual transaction that necessarily creates a morally superior world. The purchase of a lottery ticket, like any voluntary, consensual assumption of risk, often manifests a self-destructive, not a creative, human potential. If Posner's lottery metaphor - which he believes speaks for itself - illustrates anything at all, it illustrates only the poverty of a moral system that rests exclusively on one human ability, one metaphor, and one deeply ambiguous human act.

IV. The Morality of Hypothetically Consensual

Transactions: AUthoritarian Masochism and the Will TO SUBMIT TO LEgal IMPERATIVES

The final element of Posner's argument is that even nonmarket wealth-maximizing institutions can be justified by reference to the 
principle of consent. ${ }^{68}$ The sort of consent such institutions command, however, is neither express nor implied: affected parties neither expressly bargain for the reallocation the transfer entails, nor do they impliedly assume the risks of that reallocation. ${ }^{69}$ Rather, nonmarket wealth-maximizing institutions, if they are truly wealth-maximizing, command the hypothetical consent of affected parties, including potential losers. ${ }^{70}$ If a citizen were to be asked, counterfactually, whether she would prefer to accept the bundle presented by the wealth-maximizing institution - for example the high benefits in savings, combined with the low probability of devastating losses, inherent in the negligence system ${ }^{71}$ - rather than the bundle of benefits and risks entailed by systems that are not wealth-maximizing, she would prefer, and hence consent to, the bundle presented by the wealth-maximizing institution:

If a driver is injured by another driver in an accident in which neither was at fault, in what sense has the injured driver consented ... to not being compensated for his injury, which is the result under the negligence system?

To answer this question, we must consider the effect on the costs of driving of insisting on ex post compensation, as under a system of strict liability. By hypothesis the costs would be higher. . . . Would drivers be willing to incur higher costs in order to preserve the principle of ex post compensation? Presumably not. Any driver who wanted to be assured of compensation in the event of an accident, regardless of whether the injurer was at fault, need only buy firstparty, or accident, insurance - by hypothesis at lower cost than he could obtain compensation ex post through a system of strict liability. ${ }^{72}$

Posner concludes that the cheaper system will command the hypothetical consent of all affected parties. Therefore, even nonmarket wealth-maximizing institutions are consensual and justifiable according to ethics of personal autonomy:

I have used the example of negligence versus strict liability because it has been used to argue that the wealth-maximization approach is inconsistent with an approach based on notions of personal autonomy. If a requirement of consent in the sense in which I am using the term is deemed an adequate safeguard of the autonomy interest, this argument must fail unless it is shown that a strict liability system would be cheaper than a negligence system. ${ }^{73}$

6s See R. POSNER, supra note 1 , at 95 .

${ }^{69}$ See id. at $95-96$.

70 See id. at $95-97$.

${ }^{71}$ See id. at $95-96$.

72 Id. at 95 .

${ }^{73} I d$, at 96 (footnote omitted). 
Thus, although we might obey a wide array of nonmarket legal imperatives, we would consent only to those nonmarket imperatives that are wealth maximizing. It is only this subset of nonmarket legal imperatives - those that are wealth maximizing - that command not just our obedience but also our hypothetical consent. Therefore, only wealth-maximizing nonmarket imperatives are morally justifiable.

Posner's argument depends on the psychological claim that if we were asked, counterfactually, whether we consent to the nonmarket imperatives imposed upon us, we would consent to those nonmarket legal institutions, and only to those legal institutions, that are cheaper. If asked, we would give our consent to cheap, rather than expensive, legal imperatives, because we are psychologically constituted in such a way as to prefer that which maximizes our wealth. Wealth-maximizing legal institutions that satisfy the "cheapness criterion" are thus morally desirable not only because they are cheaper, but also because they are consensual and support autonomy. Given this assumption, the "autonomy interest," as Posner calls it, turns out to be coextensive with the "cheapness interest."

Kafka is also convinced that people would give their consent, were they asked, to many of the nonmarket legal imperatives that they obey. Kafka's descriptions of obedient citizens leave little doubt that, if asked, those citizens would consent to at least many, if not all, of the imperatives imposed upon them. The vast bulk of Kafka's citizens obey legal imperatives not because they fear the consequences of noncompliance, but because they generally concur in the norms and judgments those imperatives entail. Their obedience is not typically coerced; Kafka makes clear that, if asked, these citizens would consent to the norms they obey. They have tendered, in Posnerian language, their hypothetical consent to the wide array of legal (and parental) imperatives that unquestionably command their obedience.

The reasons for which Kafka's citizens would give their consent, however, differ markedly from the considerations that Posner supposes would be decisive. Whereas Posner's citizens would consent, if asked, to those legal imperatives that are wealth maximizing, Kafka's citizens are governed by a different internal psychology. Kafka's characters would consent to legal imperatives that satisfy a very different and well-specified set of cravings. Kafka's characters, if asked, would consent to impersonal state imperatives in order to satisfy an unquenchable thirst, not for wealth, but for judgment and ultimately for punishment. The legal imperatives of a state, Kafka suggests, hold out an offer we cannot refuse: an opportunity for pronouncement and hence acknowledgment of our guilt, for judgment, and for punishment.

Because of this dramatically non-Posnerian psychological assumption, the legal imperatives to which Kafka's characters would hypo- 
thetically consent, and which they do in fact emphatically obey, promote neither their well-being nor their autonomy. The legal imperatives that command the actual obedience and the hypothetical consent of Kafka's characters promote instead their feelings of guilt, inadequacy, and punitive self-doubt. In Kafka's psychologically complex world, unlike Posner's, nothing of moral significance follows from the bare fact that a citizen would, if asked, consent to the imposition upon him of any of the many legal imperatives that he dutifully obeys.

Kafka's earliest and most powerful dramatization of his psychological claim portrays a son's acquiescence to the punitive and judgmental imperative of his father. In "The Judgment," Georg's father finds Georg guilty of insensitivity, selfishness, and devilishness, and sentences him to death by drowning:

"How long a time you've taken to grow up! Your mother had to die, she couldn't see the happy day, your friend is going to pieces in Russia, even three years ago he was yellow enough to be thrown away, and as for me, you see what condition I'm in. You have eyes in your head for that!"

"So you've been lying in wait for me!" cried Georg.

His father said pityingly, in an offhand manner: "I suppose you wanted to say that sooner. But now it doesn't matter." And in a louder voice: "So now you know what else there was in the world besides yourself, till now you've known only about yourself! An innocent child, yes, that you were, truly, but still more truly have you been a devilish human being! - And therefore take note: I sentence you now to death by drowning!"74

Upon hearing the verdict, Georg is driven by internal need - not an external sanction - to acquiesce voluntarily to his father's judgment. Georg carries out the sentence of death not because he is forced to, but because he concurs in the correctness of his father's law as applied against him. In Posnerian language, Georg gives his hypothetical consent to the norm imposed upon him - if asked, he would agree that his crime of being devilish warrants the punishment of death. His obedience is not coerced by force or sanction, but is instead a product of his implicit concurrence in the accuracy of the judgment and the appropriateness of the sentence. Georg's hypothetical consent to this harsh and bizarre sentence - the death penalty for devilishness - is surely not prompted by the belief that in the long haul such a norm maximizes his wealth. Kafka makes vividly clear that, if asked, Georg would consent to such a norm because it satisfies his need for recognition of his own guilt and for punishment:

Georg felt himself urged from the room, the crash with which his father fell on the bed behind him was still in his ears as he fled. On

${ }^{74}$ F. KAFKA, The Judgment, in STORIES, supra note 9, at 87 . 
the staircase, which he rushed down as if its steps were an inclined plane, he ran into his charwoman on her way up to do the morning cleaning of the room. "Jesus!" she cried, and covered her face with her apron, but he was already gone. Out of the front door he rushed, across the roadway, driven toward the water. Already he was grasping at the railings as a starving man clutches food. He swung himself over, like the distinguished gymnast he had once been in his youth, to his parents' pride. With weakening grip he was still holding on when he spied between the railings a motor-bus coming which would easily cover the noise of his fall, called in a low voice: "Dear parents, I have always loved you, all the same," and let himself drop. ${ }^{75}$

Kafka's later parables, short stories, and novels - including of course The Trial - extend the example presented in "The Judgment" to the submission of citizens to legal and state authorities. In "The Imperial Colonel,"76 Kafka poses, without resolving, the question of why the obedient are inclined to obey. Kafka's short parable constitutes a sharp rebuke to Posner's insistent psychological claim that we would consent to the imperatives of a state when and only when those imperatives will maximize our wealth. To the contrary, Kafka's story implies that behind such hypothetical consent to the impersonal imperatives of the state lies not an urge to increase one's own wellbeing, but the urge to submit:

One is ashamed to say by what means the imperial colonel governs our little town in the mountains. His few soldiers could be disarmed immediately, if we so wished, and help for him, even supposing he could summon it - but how could he do that? - would not come for days, indeed for weeks. And so he is utterly dependent on our obedience, but he does not try either to enforce it by tyrannical means or to wheedle it out of us by cordiality. And so why do we tolerate his hated rule? There is no doubt about it: only because of his gaze .... ${ }^{77}$

In the parable "The Emperor,"78 Kafka shifts his attention away from the ruler and focuses on the mechanism of consent itself. Why would we, if asked, consent to legal imperatives? We would consent, the parable suggests, not because it is wealth maximizing to do so, but because it is psychologically satisfying, or perhaps necessary, to believe in the divine authority or the natural superiority of those with power. It is this psychological compulsion, not any state force, that ultimately quiets doubts as to the law's transcendent authority:

A man doubted that the emperor was descended from the gods; he asserted that the emperor was our rightful sovereign, he did not doubt

${ }^{75} \mathrm{Id}$. at $87-88$.

76 F. KAFKA, The Imperial Colonel, in STORIES, supra note 9, at 475.

${ }^{77}$ Id. at $475-76$.

${ }^{78}$ F. KAFKA, The Emperor, in StoRIEs, supra note 9, at 476. 
the emperor's divine mission (that was evident to him), it was only the divine descent that he doubted. This, naturally, did not cause much of a stir; when the surf flings a drop of water on to the land, that does not interfere with the eternal rolling of the sea, on the contrary, it is caused by it. ${ }^{79}$

In the short story "The Refusal," 80 Kafka provides a psychological account of the legitimating urge for divine or supernatural authority upon which successful rule depends. Kafka's protagonist describes his own perception of the psychological process through which the governed come to perceive state authority and state judgments as legitimate, which in turn leads them to tender their hypothetical consent to the state's imperatives:

Now it is remarkable and I am continually being surprised by the way we in our town humbly submit to all orders issued in the capital. For centuries no political change has been brought about by the citizens themselves. In the capital great rulers have superseded each other - indeed, even dynasties have been deposed or annihilated, and new ones have started ... yet none of this had any influence on our little town. ... The highest official is the chief tax-collector, he has the rank of colonel, and is known as such. . .

This colonel, then, commands the town. I don't think he has ever produced a document entitling him to this position; very likely he does not possess such a thing. Maybe he really is chief tax-collector. But is that all? Does that entitle him to rule over all the other departments in the administration as well? . . . One is almost under the impression that the people here say: "Now that you've taken all we possess, please take us as well." In reality, of course, it was not he who seized the power, nor is he a tyrant. It has just come about over the years that the chief tax-collector is automatically the top official, and the colonel accepts the tradition just as we do. ${ }^{81}$

It has also "just come about" that the colonel regularly and ceremonially denies petitions from members of the community. Those denials are not simply tolerated; they are met by the "undeniable relief" of the community. Thus, the citizens' obedient compliance with the colonel's denials reflects not the coercive influence of force, but the citizens' hypothetical consent to the impersonal imperatives of the government. Force is not needed because, if asked, the citizens would consent to the denials arbitrarily imposed upon them. That hypothetical consent is in turn motivated, Kafka suggests, by the seductive appeal of punitive hierarchy. If the citizens were asked, they would give their consent to these denials not because the denials maximize their wealth, but because they satisfy their need for self-

80 F. KAFKa, The Refusal, in STORIEs, supra note 9, at 263.

s1 Id. at $263-64$. 
denial and adverse judgment. The citizens are inclined to legitimate the state with their hypothetical consent to its imperatives because it feels good to be ruled and to be denied, not because those imperatives serve their well-being:

"The petition has been refused," he announced. "You may go." An undeniable sense of relief passed through the crowd, everyone surged out ....

In all important matters, however, the citizens can always count on a refusal. And now the strange fact is that without this refusal one simply cannot get along, yet at the same time these official occasions designed to receive the refusal are by no means a formality. Time after time one goes there full of expectation and in all seriousness and then one returns, if not exactly strengthened or happy, nevertheless not disappointed or tired. About these things I do not have to ask the opinion of anyone else, I feel them in myself, as everone does; nor do I have any great desire to find out how these things are connected. 82

Kafka's masterpiece The Trial explores the ramifications of our masochistic submission to authority when the state is considerably more malignant than the states that appear in the parables. At the outset of the novel, Joseph $\mathrm{K}$. is arrested "without having done anything wrong." 83 Joseph never learns the nature of the charges brought against him. The state and its officials are unpredictable and sadistic. Yet Joseph is never physically forced to do anything: he is arrested but not imprisoned; he is interrogated but never forced to appear; he is tried but never held against his will. Instead, he comes to accept the jurisdiction and legality of the court, its authority, its legitimacy, and ultimately its omnipotence and omniscience. Thus, Joseph does not simply obey the state's imperatives; his acquiescence is far more complete. By the end of the year, Joseph acknowledges the court's and the law's authority, concurs in the verdict against him, and complies in his own death sentence.

The horror and the familiarity of The Trial stem only superficially from the lawlessness of the legal system and the state's exercise of power. More fundamentally, the horror stems from Joseph's willing acquiescence to this corrupt authority - his hypothetical consent to, or legitimation of, the mindless, sadistic force being applied against him. In the last paragraphs, as Joseph is being led to the spot of his execution, his acquiescence is total, his identification with his warders complete. The sole comfort he allows himself is contemplation of the lesson that acquiescence has taught him:

83 F. Kafka, The Trial 7 (1956). 
$[\mathrm{H}] \mathrm{e}$ suddenly realized the futility of resistance. There would be nothing heroic in it were he to resist, to make difficulties for his companions, to snatch at the last appearance of life by struggling. He set himself in motion, and the relief his warders felt was transmitted to some extent even to himself. They suffered him now to lead the way .... "The only thing I can do now," he told himself ..., ["]is to keep my intelligence calm and analytical to the end. I always wanted to snatch at the world with twenty hands, and not for a very laudable motive, either. That was wrong, and am I to show now that not even a year's trial has taught me anything? Am I to leave this world as a man who has no common sense? ... I don't want that to be said." $\$ 4$

Only at the moment of execution does Joseph refuse to lend his affirmative assistance in what is happening to him. He experiences even this refusal, however, as an inability, rather than as an affirmative act of resistance:

Once more the odious courtesies began, the first handed the knife across $\mathrm{K}$. to the second, who handed it across $\mathrm{K}$. back again to the first. $K$. now perceived clearly that he was supposed to seize the knife himself, as it traveled from hand to hand above him, and plunge it into his own breast. But he did not do so, he merely turned his head, which was still free to move, and gazed around him. He could not completely rise to the occasion, he could not relieve the officials of all their tasks; the responsibility for this last failure of his lay with him who had not left him the remnant of strength necessary for the deed. . . .

But the hands of one of the partners were already at K.'s throat, while the other thrust the knife deep into his heart and turned it there twice. . . . "Like a dog!" he said; it was as if the shame of it must outlive him. ${ }^{85}$

What motivates Joseph K.'s compliance? As in so much of Kafka's legal fiction, it is neither fear nor threat of force; Joseph's obedience is not coerced from him. Instead, Joseph $\mathrm{K}$. complies with his trial and execution because, like Georg of "The Judgment," he concurs in the verdict against him and in the appropriateness of the punishment. In Posnerian terms, Joseph $\mathrm{K}$. would consent, if asked, to the verdict of guilt and would agree that death is the appropriate sanction for his unspecified crime. As with the depiction of Georg, Kafka leaves little doubt about what would motivate such hypothetical consent: Joseph $\mathrm{K}$. would consent to the punitive norms imposed upon him not because those norms in the long run maximize his wealth, but because they acknowledge his sense of guilt and satisfy his craving for punishment. 
Finally, in a short parable entitled "The Problem of Our Laws,"86 Kafka straightforwardly describes his vision of the nature of law and legal authority, and the mechanism of legitimation upon which it depends. The authority of law, Kafka tells us, is ultimately sustained not by force, but by the craving of the governed for judgment by lawful, "noble" authority. It is this human craving, even more than the urge of the powerful to dominate, that sustains the illusion of certainty, fairness, generality, and justice. We would consent to the imperatives of our laws and of the nobility that controls them, not because it would be in our interest to do so, but because we desire to see nobility in those who judge us and because we desire to be judged by those we see as noble. It is that craving that motivates our hypothetical consent to the imposition of laws whose substance we do not even know:

Our laws are not generally known; they are kept secret by the small group of nobles who rule us. ...

The very existence of these laws, however, is at most a matter of presumption. There is a tradition that they exist and that they are a mystery confided to the nobility, but it is not and cannot be more than a mere tradition sanctioned by age, for the essence of a secret code is that it should remain a mystery. ... There is a small party who ... try to show that, if any law exists, it can only be this: The Law is whatever the nobles do. This party see everywhere only the arbitrary acts of the nobility, and reject the popular tradition, ... for it gives the people a false, deceptive, and overconfident security in confronting coming events. ...

... Any party that would repudiate not only all belief in the laws, but the nobility as well, would have the whole people behind it; yet no such party can come into existence, for nobody would dare to repudiate the nobility. ... The sole visible and indubitable law that is imposed upon us is the nobility, and must we ourselves deprive ourselves of that one law?87

If Kafka's descriptions ring true - if we would consent when asked, not to those legal imperatives that promote our wealth or selfinterest, but to those that satisfy our cravings for judgment and punishment by noble authority - then nothing of moral consequence can follow from the fact of our hypothetical consent. It does not follow that the imperative to which we would hypothetically consent is one that will serve either our enlightened or our perceived selfinterest. It does not follow that the hierarchical relationship between us and the state to which we hypothetically consent, and which we thereby hypothetically legitimate, is a good one. It does not follow that the institutions to which we hypothetically consent are just or

${ }^{86}$ F. KAFKa, The Problem of Our Laws, in STORIEs, supra note 9, at 437.

${ }^{87}$ Id. at $437-38$. 
that the hypothetical choices we make are choices that reflect, much less foster, autonomy. If, as Kafka suggests, we are motivationally inclined to submit to authority, we must examine the value of the hierarchical relationships that the act of submission creates. The fact of submission, like the fact of consent, in itself implies nothing.

Thus, even if nonmarket legal institutions would command our consent, nothing normative follows from that assumption. Posner has not shown that we would consent, if asked, only to those legal imperatives that leave us better off, or that reinforce autonomous virtues, or that are morally superior, or even that are cheaper. He simply assumes that we would give our consent to all legal imperatives that are wealth-maximizing, and to none that are not. A nonmarket legal imperative indeed may be morally preferable if it is cheaper. But the argument supporting such a proposition can draw nothing from the consent that we may be inclined to give it.

Why might we give our consent to particular nonmarket legal institutions if we were asked to do so? We might consent, as Posner suggests we invariably would, because of the high odds that the nonmarket institution will leave us wealthier than some other alternative. ${ }^{\$ 8}$ We might, however, give our consent to such nonmarket legal institutions because of their authoritarian and punitive structure. "Nonmarket legal institutions" embody legal imperatives: "Don't fix prices." "Don't kill another human being." "Don't drive negligently." Obedience to the legal imperatives of the impersonal state and our willingness to legitimate that authority may be as ingrained as an instinct for self-preservation. Thus, if asked, we might be inclined to consent to wealth-maximizing legal imperatives of the state not because they are wealth-maximizing, but simply because we are attracted to the authoritarian structure of law. Similarly, we may be inclined to buy a lottery ticket not because the bundle of risks it presents will maximize our welfare, but simply because we are attracted to the authoritarian structure of fate.

An assessment of the moral value of that to which we would hypothetically consent must include an assessment of the relationship flowing from the transaction. Hypothetically consensual submission to legal authority does not necessarily imply a change for the better. As with our expressly consensual submission to personal authority, and impliedly consensual submission to risk, our willingness to legitimate - through our hypothetical consent - the relinquishment of a measure of our autonomy to legal imperatives has obvious prudential, moral, and social value. When we hypothetically consent to the imposition upon us of a state imperative, we are freed from the burden of resolving on our own course of action. When we hypothetically 
consent to the imposition of legal imperatives ordering us not to kill, fix prices, steal, or commit adultery, we have at the same time freed ourselves from the burden of reaching those decisions independently. Obedience to legal rules to which we would have consented relieves us of the task of evaluating the morality and prudence of our own actions, a task that would be time-consuming and perhaps beyond our powers. ${ }^{89}$ If we want to lead moral lives, both for the sake of virtue and for the sake of others, the best way to do so may be simply to obey - whether we choose to obey God's commandments, Kant's categorical imperative, the utilitarian's command to maximize the community's happiness, or the state's criminal code. The impulse to legitimate those imperatives by tendering our hypothetical consent facilitates that obedience. The impulse to legitimate our submission to imperative authority also has within it, of course, the seeds of tragedy. That impulse is the means by which we most commonly victimize ourselves, and the means by which we allow ourselves to become tools that enable those who use us to destroy others.

Thus, hypothetically consensual submission to legal authority and the loss of power and responsibility that follows may have morally desirable or morally abhorrent consequences. The hypothetical consent of the judge, citizen, and lawyer to the nonmarket imperatives of the Nazi state, although arguably excusable, was certainly not morally good. Similarly, the hypothetical consent of a citizen to the legal imperatives of a participatory democracy, although not exemplary of autonomous virtue, is certainly not evil. Our tendency to legitimate lawful authority - to give our hypothetical consent - may have good or evil consequences, depending upon the moral value of the legal system to which we have submitted and the moral quality of the relationship between state and citizen that our consent nurtures. If we are attracted to the power and punitive authority of the state, and if this attraction accounts for our tendency to consent to its imperatives, a good deal of harm may come from our persistent denial of the potential for both evil and virtue inherent in this central aspect of our nature.

\section{Conclusion}

Posner's normative defense of wealth-maximization rests on an inadequate picture of human nature. Although Posner has not expressly addressed the relevance of truth or falsity to moral theory, he justifies his admittedly over-simplified picture of our nature on the ground of scientific theory. It is not realism, but predictive value, Posner claims, that is the test of positive theory:

${ }^{89}$ See, e.g., Raz, Authority and Justification, 14 PHIL. \& PUB. AfF. 3 (1985). 
[A]n economic theory of law . . . will not capture the full complexity, richness, and confusion of the phenomena. . . But its lack of realism, far from invalidating the theory, is the essential precondition of theory. ... The true test of a theory is its utility in predicting or explaining reality. Judged by this criterion, economic theory, despite (because of ?) the unrealism of its assumptions, may be judged a success. ${ }^{90}$

In a famous passage of Kafka's The Trial reminiscent of Posner's claim, a priest explains that necessity, not truth, is that on which the powerful rely: "No," said the priest, "it is not necessary to accept everything as true, one must only accept it as necessary." Joseph's response to this lesson sounds like a warning: "A melancholy conclusion," said K. "It turns lying into a universal principle." 1

False or unrealistic premises may not defeat a scientific theory, but when we allow such premises to ground a moral theory - to dictate what we should do, as well as what we will do - we indeed run the risk of elevating lying to the level of principle. It does matter, for purposes of moral truth and moral theory, what we are like. Posner and Kafka both examine worlds in which citizens typically consent to an array of authorities - family, state, employer. Their characters, however, evince drastically different human personalities, and the moral attractiveness of the worlds they inhabit varies accordingly. Posner's hypothetical legal actors expressly, impliedly, and hypothetically consent to changes in their circumstances with a view toward the improvement of their own welfare, whereas Kafka's protagonists expressly, impliedly, and hypothetically consent because of a felt compulsion to legitimate the will of an authority. Perhaps both portraits are caricatures; Kafka's protagonists may be as unrealistically masochistic as Posner's are unrealistically egoistic. But although the masochism of Kafka's characters is exaggerated, we can nevertheless recognize glimpses of ourselves in these characters. Kafka's characters help us to see that Posner's actors are also exaggerations. It may be true, as Bentham thought, that "all men calculate." 92 It is not true, as Posner blithely assumes, that all men calculate all of the time. Sometimes we calculate. Other times, we simply obey, acquiesce, or submit.

If we are motivationally complex, then we cannot delegate to any ambiguously motivated human act such as consent the task of moral legitimation. We cannot infer that a consensual world leaves every individual better off (and is therefore morally superior) simply because all affected parties have consented to it, unless everyone was trying to improve his individual welfare when consenting to change - and

90 R. POSNER, supra note $\mathrm{II}$, at $\mathrm{I} 3$.

91 F. KAFKA, The TRIAL 246-47 (1956).

92 See supra note 25. 
succeeding. The traditional moral or legal theorist can accommodate our psychological complexity in one of two ways. First, if the theorist retains welfare as the criterion of moral decisionmaking, then that welfare must be ascertained by reference to indicia other than consent. Alternatively, if consent is the criterion of moral decisionmaking, then the moral theorist must establish the value of consent by some means other than the automatic implication of an increase in individual wellbeing. She must similarly establish the fact of autonomy by some means other than its automatic implication from an "opportunity for choice." Posner's attempted merger of consequentialist and deontological moral reasoning through the "operational" mechanism of consent fails if we sometimes consent for reasons unrelated to our own wellbeing.

A consequentialist's moral evaluation of a particular consensual transaction must address all changes actually brought on by a transaction, not just those that are presumed to have been intended. I have argued that if we are creatures predisposed to accept authority and hierarchy, we will consent to many transactions in order to submit to power, not to increase our own well-being. The new hierarchical societies we thereby create may be damaging, as are many of the relationships Kafka hypothesizes and explores. ${ }^{93}$

If the deontological theorist retains consent as the only legitimating moral criterion despite our motivationally complex reasons for giving consent, she must account for this preference. People expressly, impliedly, and hypothetically consent to a wide range of changes in our world. Many of those acts of consent seem to be morally unattractive human decisions that leave the world a morally unattractive place. Our express consent may be driven by a rational assessment of our choices, or it may spring from fear, hysteria, feelings of inadequacy, or masochistic compulsion. It is not obvious why consent driven by any of the latter should be regarded as a morally appealing human act. Similarly, we impliedly consent to assume a wide range of risks, and we do so for a wide range of reasons. Sometimes assuming these risks is rational, justified, or otherwise morally appealing, but at other times it is not. The entrepreneur may be taking a worthy risk when he enters his own business. The customer of the San Francisco bathhouse, however, may not be taking a risk worth respecting when he purchases a bundle of consensual sex and a high risk of AIDS, just as the sixteenth-century libertine may not have been taking a risk

93 Alternatively, we may occasionally consent to transactions neither to increase our individual well-being nor to create a hierarchy, but instead to create an equal community of some sort. Noncommercial consensual transactions, such as the equalizing bonds of marriage, friendship, love, and family, are not motivated exclusively by either hierarchy or self-interest, but by an inclination to create a shared point of view or equality of outlook. If so, a consequentialist account of such a transaction must evaluate the moral quality of the community thereby created. 
worth respecting when he purchased from a prostitute a bundle of consensual sex plus a high risk of syphilis-induced death. Respect for the courage of the entrepreneur should not compel respect for the destructive inclinations of the others. Finally, if asked, we would also consent to the authority of nonmarket institutions for many reasons: because we recognize the virtue of the values the institution reflects, because we think of the institution as operating for the most part in our self-interest, or because consenting to authority confirms our feeling of guilt and meets our need for punishment. It is not obvious why consent motivated by the latter two reasons should compel the same respect as does consent to a morally defensible authority motivated by rational desires.

People consent to changes in the world that involve a wide range of market choices, risk pools, and apparent authorities. Wives submit to abusive husbands; employees consent to exploitative and humiliating work environments; consumers consent to sales of defective, dangerous, and over-priced merchandise; women consent to "date rape" and to sexual harrassment on the street and on the job; religious converts submit to directives compelling consensual suicide; subjects in an experiment consent to the dehumanizing, authoritative instruction to electrically shock other human beings; monks consensually abide by "vows" of poverty; Zen students consensually endure assaults by their teachers; patients in therapy abide the directives of their therapists; soldiers follow the orders of their superiors; and citizens generally obey, without need of coercion, the legal injunctions of their governments. Many of those consensual changes leave both individual and community not just worse off, but miserable. It is not obvious why we should assume that all of these consensual changes in the world are moral changes on the ground that they promote autonomy. It does not follow from the fact that coerced states are immoral by virtue of their coercive element that voluntary world states are of positive moral value by virtue of their voluntariness.

Finally, a moral theorist may coherently and perhaps sensibly insist that for some purposes we ought to forgo concern for both utility and consent, and justify actual or proposed institutions by reference to the moral value of the human personality they engender. But in order to do so and remain true to that human personality, we need to develop rich and true descriptions of the subjective experience of our institutions. We live the subjective experience of our lives, not their formal, conventional, outward descriptions. Our subjective experiences of the consensual transactions we enter do not accord with Posner's external descriptions of those transactions. From the external point of view, we consensually choose to move from state $A$ to state $B$. But from an interior perspective, we experience that act in any number of complex ways - as a submission to a perceived or actual authority suggesting or mandating a change, as the imposition of a change upon 
a resisting party, as an agreement to a change with a newly discovered equal partner. Submission, imposition, and agreement imply a conscious will to create a new community through human interaction at the same time that they evidence a will to effect a reallocation of resources. That implication is lacking in the starkly solitary act of choice. Submission and imposition also imply a will to create a hierarchical community through human interaction. That further implication is lacking in the equalizing act of reaching agreement. The act of consent is a broad description that only outwardly, and only transparently, embraces all of these radically different subjective experiences.

In only one respect are these widely disparate consensual decisions subjectively alike: no one of them by itself constitutes the essence of the experience of being human. No one of these consensual acts, and certainly not the act of consent itself, should define the essential experience of morality. Moral theory, if not scientific theory, must be about truth, not necessity. Our assessment of the moral significance of our legal institutions cannot be based upon necessary depictions of human nature. We must attain a true depiction, indeed we must attain many true depictions, of the joys and sufferings to which we give our consent. Only then can we assess the wisdom of imposing those experiences upon others. 